\title{
Evaluation of a single-shot gonadotropin-releasing hormone (GnRH) immunocontraceptive vaccine in captive badgers
}

\author{
Dave Cowan ${ }^{1,2} \cdot$ Graham C Smith $^{1} \cdot$ Matt Gomm $^{1} \cdot$ Matt Brash $^{3} \cdot$ Fiona Bellamy $^{1} \cdot$ Giovanna Massei $^{1}$. \\ Rachael Conwell ${ }^{4}$. Flavie Vial ${ }^{1}$
}

Received: 19 February 2019 / Revised: 5 June 2019 / Accepted: 14 June 2019 / Published online: 1 July 2019

(C) The Author(s) 2019

\begin{abstract}
GonaCon, a single-shot injectable immunocontraceptive vaccine targeting the gonadotropin-releasing hormone (GnRH), has been tested in key mammal species in the UK and shown to be a safe method to reduce population size in areas of high human wildlife conflict. Badgers exhibit an unusual reproductive physiology in that females may maintain fertilised eggs and dormant blastocysts at any time of year and delay their implantation until the winter. It is thus necessary to evaluate the consequences of delayed implantation and timing of vaccination on the effectiveness of GonaCon for fertility control of female badgers. We found that vaccination in June had an immediate effect on the fertility indicators monitored and inhibited subsequent cub production in the following year, while vaccination in November had no effect. Further results suggest that the optimal vaccination window in badgers could be as narrow as between June and August. The longer-term effectiveness of GonaCon vaccination in female badgers appears to reflect maintenance of anti-GnRH antibody titres at or above a putative threshold titre of 1:128,000, a threshold higher than that reported for other species (1:64,000). While it is possible that using a larger dose $(>1 \mathrm{~mL}) \mathrm{might}$ lead to longer lasting effects, this study shows that vaccination would need to be repeated at least every 2 years in order to maintain levels of female infertility predicted to have demographic impacts on badger populations. Overall, no negative welfare consequences were observed in vaccinated badgers indicating that GonaCon is a potential tool for the management of conflicts involving badgers.
\end{abstract}

Keywords Meles meles $\cdot$ Fertility control $\cdot$ Immunocontraception $\cdot$ Vaccination

Electronic supplementary material The online version of this article (https://doi.org/10.1007/s10344-019-1296-0) contains supplementary material, which is available to authorized users.

\author{
Flavie Vial \\ flavie.vial@apha.gov.uk \\ Dave Cowan \\ wildlifeconsultingint@gmail.com \\ Graham C Smith \\ graham.smith@apha.gov.uk \\ Matt Gomm \\ matt.gomm@apha.gov.uk \\ Matt Brash \\ matt.brash@btinternet.com \\ Fiona Bellamy \\ Fiona.bellamy@apha.gov.uk

\author{
Giovanna Massei \\ Giovanna.massei@apha.gov.uk \\ Rachael Conwell \\ rcconwell@gmail.com
}

1 National Wildlife Management Centre, Animal and Plant Health Agency (APHA), Sand Hutton Campus, Sand Hutton, York YO411LZ, UK

2 School of Natural and Environmental Sciences, Newcastle University, Newcastle upon Tyne NE1 7RU, UK

3 ARKVETS, Givendale House, Givendale, Pocklington YO42 ITT, UK

4 EquiMed Referrals Ltd, New Grange Farm, Ingham Lane, Halifax, West Yorkshire HX2 9PE, USA 


\section{Introduction}

Fertility control offers a potential non-lethal approach for reducing mammal abundance in the resolution of conflicts between wildlife and human interests (Fagerstone et al. 2010; Massei and Cowan 2014). Compared to culling, fertility control has the potential disadvantage that it will generally take longer to achieve equivalent population reductions, simply because infertile animals will remain in the population until they die (Hone 1992). However, fertility control also offers potential advantages over culling, for example by reducing vertical transmission of disease (mother to offspring), which in turn reduces the probability of disease maintenance within a population (L. A. Miller et al. 2004b). In addition, should the body condition and general health of animals in the population be increased following the induction of infertility (as infertile individuals do not accrue the physiological costs of reproduction), individual susceptibility to disease should be reduced leading to decreasing disease transmission and incidence in the whole population. Fertility control can also result in behavioural changes in individuals that reduce disease contact rates (Caley and Ramsey 2001; Dave Ramsey 2007; D. S. Ramsey et al. 2006) and should cause less short-term social perturbation (likely to increase disease transmission) than culling (Tuyttens and Macdonald 1998). Fertility control can be applied in parallel to other types of disease control interventions. It is particularly effective at maintaining populations at an appropriate lower density after initial reduction by culling (Merrill et al. 2003; White et al. 1997) and can potentially work synergistically with disease vaccination (Carroll et al. 2010; G. C. Smith and Cheeseman 2002) with the reduction in young of the year increasing the efficacy of vaccination for disease control (G.C. Smith and Wilkinson 2003). Immunocontraception, using a vaccine to generate an immune response to some key component of the target's reproductive system, has moved from theory into practice with the development of "single-shot" injectable vaccines (Curtis et al. 2002; L. A. Miller et al. 2000). This has culminated with the formulation of the single-shot injectable immunocontraceptive GnRH vaccine GonaCon, registered in the USA for white tailed-deer (Odocoileus virginianus), feral horses (Equus caballus) and burros (Equus asinus) in the USA. GonaCon generates antibodies to the gonadotropinreleasing hormone $(\mathrm{GnRH})$, a key hormone that regulates steroid hormones (oestrogens, progesterone and testosterone). The down-regulation of GnRH reduces levels of these hormones and treated females and males can remain infertile for several years following vaccination. GonaCon has been tested in many mammal species and shown to be a safe and effective single-dose GnRH-based immunocontraceptive vaccine (Massei and Cowan 2014; Massei et al. 2008).

In the UK, bovine tuberculosis (bTB), caused by M. bovis, is a major cattle health issue, with currently around $6.0 \%$ of
non-Officially Tuberculosis Free herds in England (12\% in the high-risk area). ${ }^{1}$ The European badger (Meles meles) is a reservoir of bTB in the UK where the densities of this species are considered to be the highest in Europe (G.C. Smith 2002). The control of badger populations by culling has been shown to reduce the incidence of bTB in cattle inside the culling areas (Brunton et al. 2017; Jenkins et al. 2010). However, culling disrupts the local badger population structure, and remaining animals tend to move longer distances and visit neighbouring social groups more frequently (Carter et al. 2007; R. Woodroffe et al. 2009). This perturbation effect was associated with higher risks of bTB in surrounding cattle herds (R. Woodroffe et al. 2009). A non-lethal approach for managing badger populations would therefore be a potentially attractive new strategy for reducing risks of bTB transmission from badgers to cattle, especially if this was not expected to cause a perturbation effect. As it is increasingly recognised that fertility control and disease vaccination could complement each other with respect to disease management (Carroll et al. 2010), future use of fertility control in badgers could be in association with the licenced TB vaccine for Badger BCG (Chambers et al. 2011; Lesellier et al. 2011). Fertility control could also be used to manage extant urban badger problems. Badger numbers have increased in England and Wales (Judge et al. 2014), and populations have increasingly become urbanised (S. Harris et al., 2010), in some instances causing intense and persistent local problems (Stephen Harris 1984; Delahay et al. 2009). However, several key issues must be addressed prior to rolling out fertility control as a new population control management method in situ: these include testing the effectiveness and potential side effects of GonaCon in the new species (in our case, badgers) in pilot captivity trials, monitoring the longevity of effect of GonaCon in badgers and assessing the feasibility and cost of employing fertility control in the field.

Among mammals, badgers are characterised by an unusual reproductive physiology. Mating can take place at any time of year and parturition from December until July, although there is a peak in mating behaviour from February to May, and a peak in births from January until May. Consequently, female badgers may be pregnant (that is, may maintain fertilised eggs and dormant blastocysts) at any time of year. Delayed implantation ensures that the vast majority of blastocysts implant during the winter. It is therefore likely that many females would already maintain fertilised eggs or blastocysts by the time they could be vaccinated with GonaCon by injection, given the recommended close season on trapping and treating badgers which extends from December to May (Defra 2018). Fertilised eggs and blastocysts are maintained in the lumen of the uterus by progesterone, which is secreted by corpora lutea

\footnotetext{
${ }^{1}$ Official detailed statistics on bTB in cattle in Great Britain published on 14/ 02/2018 https://www.gov.uk/government/statistical-data-sets/tuberculosis-tbin-cattle-in-great-britain
} 


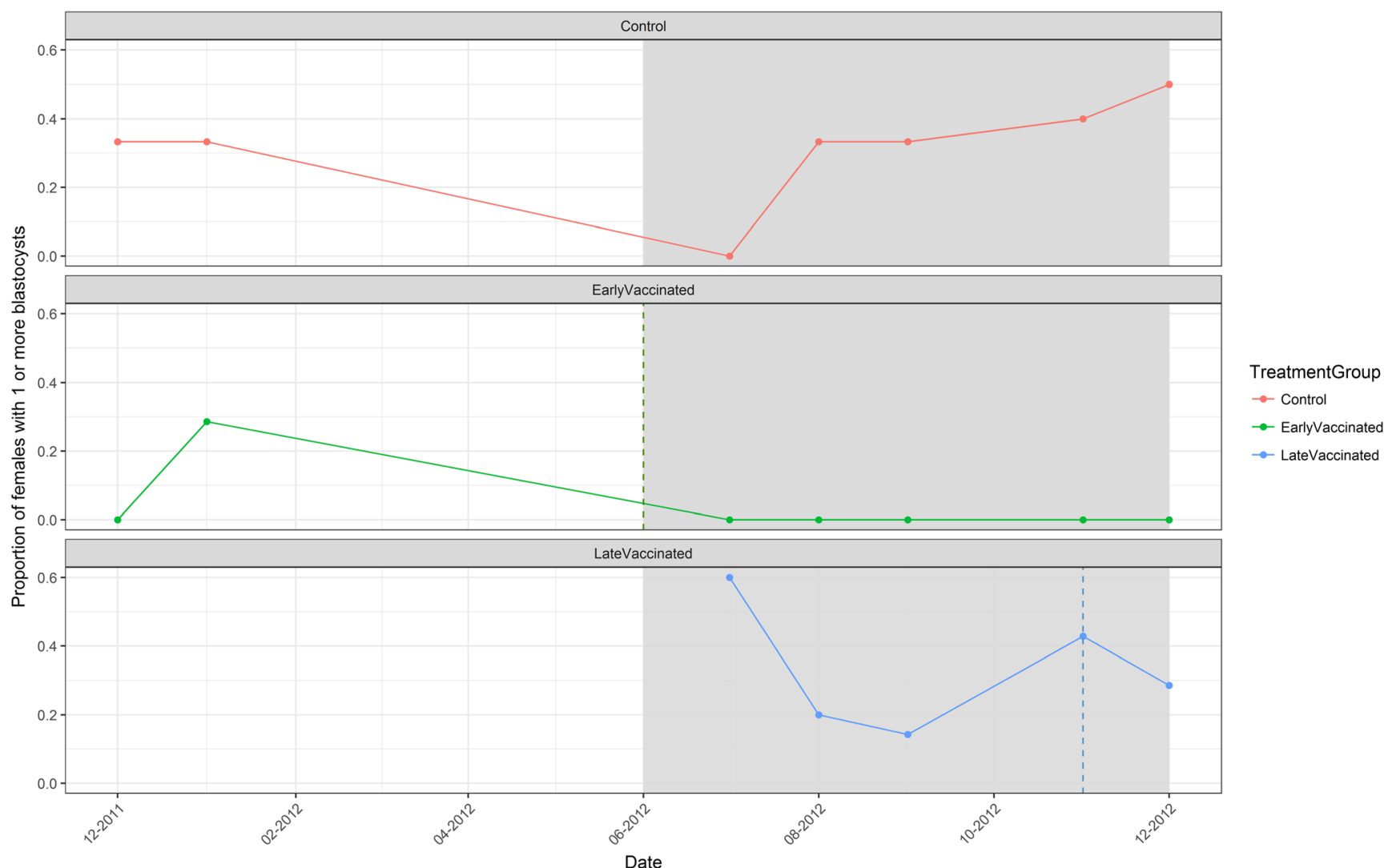

Fig. 1 Proportion of females with at least one blastocyst identified by ultrasound between June and December in the early vaccination, late vaccination and control groups. The dashed lines mark the dates for the

formed in the ovaries at ovulation (E. G. Neal and Harrison 1958), although at very low concentrations in comparison with other mammals (Yamaguchi et al. 2006). Implantation into the wall of the uterus is governed by oestrogen and progesterone, which under experimental conditions are influenced by day length (Canivenc and Bonnin 1979). However, under natural conditions, Neal and Cheeseman (1996) argued that the high degree of within- and between-site variation in date of implantation implies that day length (or night length) does not provide a consistent explanatory factor. Moreover, the ovaries secrete very little oestrogen and progesterone during embryonic diapause and the peak period of implantation (Page et al. 1994), which is contrary to regulation of hormone production by exogenous cues. Neal (1977) hypothesised that production of oestrogen and progesterone by the ovaries in spring resulted in their uptake into body fat (steroids are soluble in fat, and progesterone is known to be stored in fat in mammals) and that the release of these hormones during winter, when body fat is metabolised, promotes blastocyst implantation. Ovarian progesterone (and some other hormones such as prolactin, which is produced via a distinct hormone cascade) is known to drive implantation after embryonic diapause in American mink (Murphy et al. 1983). A major pulse in GnRH production immediately precedes ovulation and results early vaccination (green-June 2012) and the late vaccination (blueNov 2012) with GonaCon. The grey shading delimits the time period of interest for comparison between the experimental groups

in considerable production of oestrogen and progesterone, and it is possible that this results in sufficient storage of these steroids to promote implantation as fat is metabolised, and hormones released during the winter. Consequently, it is possible that, if breeding badgers are treated after they had already conceived, diapausing blastocysts will be maintained independently of further ovarian secretion (or rather lack of secretion due to vaccination with GonaCon) of GnRH from active corpora lutea. Corpora luteal activity is maintained independently of hypophyseal and gonadotrophic support in some other species that exhibit delayed implantation such as certain marsupials (Hearn 1974; Hinds et al. 1983). Nevertheless, if sufficient progesterone is released from body fat, implantation of the blastocysts might in any case be independent of the hormone cascade caused by GnRH secretion. Thus, the availability of progesterone in stored fat and the continued natural production of prolactin might allow pregnancies to go full term.

This study directly addressed the question of whether delayed implantation affects the immediate impact of GonaCon on badger fertility in captive females. The mode of action of GonaCon can potentially reduce levels of reproductive androgens, specifically testosterone, in male mammals thereby compromising sperm production and, hence, inducing 


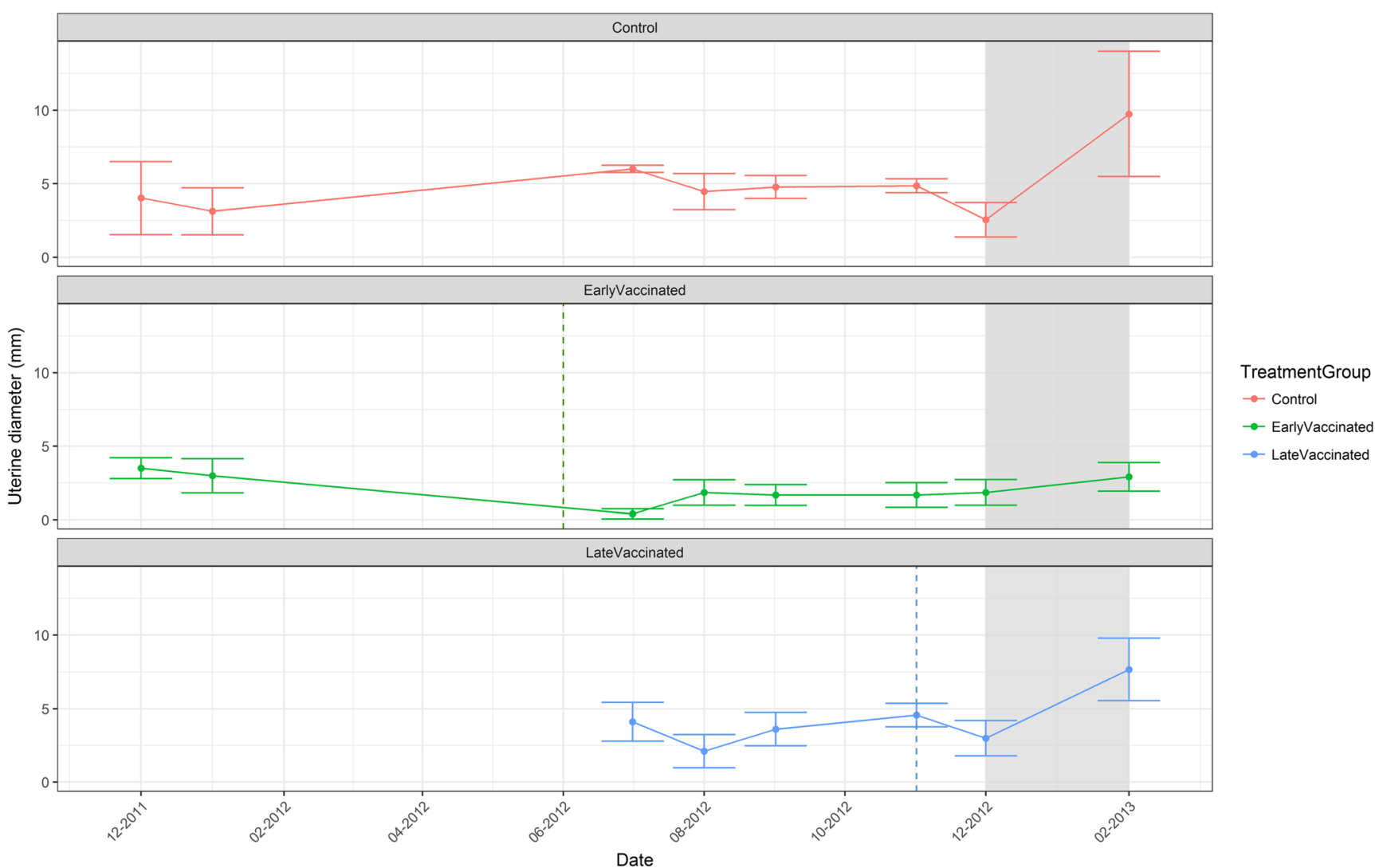

Fig. 2 Variation in mean $( \pm \mathrm{SE})$ uterine diameter $(\mathrm{mm})$ for the early vaccination, late vaccination and control groups. The dashed lines mark the dates for the early vaccination (green-June 2012) and the late vaccination (blue-Nov 2012) with GonaCon. The grey shading delimits the time period of interest for comparison between the experimental groups infertility. For instance, reduced testosterone and sperm counts have been demonstrated in male cats, male dogs, and male deer (Levy et al. 2004; Lowell A. Miller et al. 2004a). The present study also examined the effects of GonaCon on male badgers because during application of GonaCon by injection in the field, it would be difficult to reliably discriminate between males and females in traps. Furthermore, although male infertility is likely to be relatively unimportant demographically, it might augment reduced female fertility in terms of additional reductions in cub production.

This study initially established breeding in captive badgers before monitoring their reproductive physiology and cub production over 2 years following a single inoculation with GonaCon vaccine. The objectives of the study were

1. To evaluate the consequences of delayed implantation and timing of vaccination on the effectiveness of GonaCon for fertility control in female badgers.

2. To evaluate the longevity of infertility induced by GonaCon in female badgers by determining the putative titre level below which infertility is reversed.

3. To monitor potential negative side effects associated with GonaCon in both male and female badgers.

\section{Methods}

\section{Study animals}

Study animals were obtained from areas where bTB is not endemic in cattle and is not known to persist in badgers. Individuals were given a full health check on being brought into captivity, and blood samples were collected for biochemical assessment. Each individual was uniquely marked with a PIT tag. All animals tested negative for bTB using the IFN $\gamma$ ELISA (enzyme-linked immunosorbent assay) ImmunoAssay (EIA) (Dalley et al. 2008).

The animals were housed at a Good Laboratory Practice (GLP) compliant specialist animal facility in enclosures each consisting of a solid roofed and concreted area measuring $8 \mathrm{~m} * 5 \mathrm{~m}$ with access to a mesh roofed grassed area of $20 \mathrm{~m}$ by $5 \mathrm{~m}$. Each enclosure included six wooden lidded enclosed shelters ("setts") and was enriched with an assortment of digging and burrowing opportunities as well as pools. Two males and two females were housed in each enclosure; individuals were randomly assigned to enclosures irrespective of their treatment group. A complex feeding regime was 


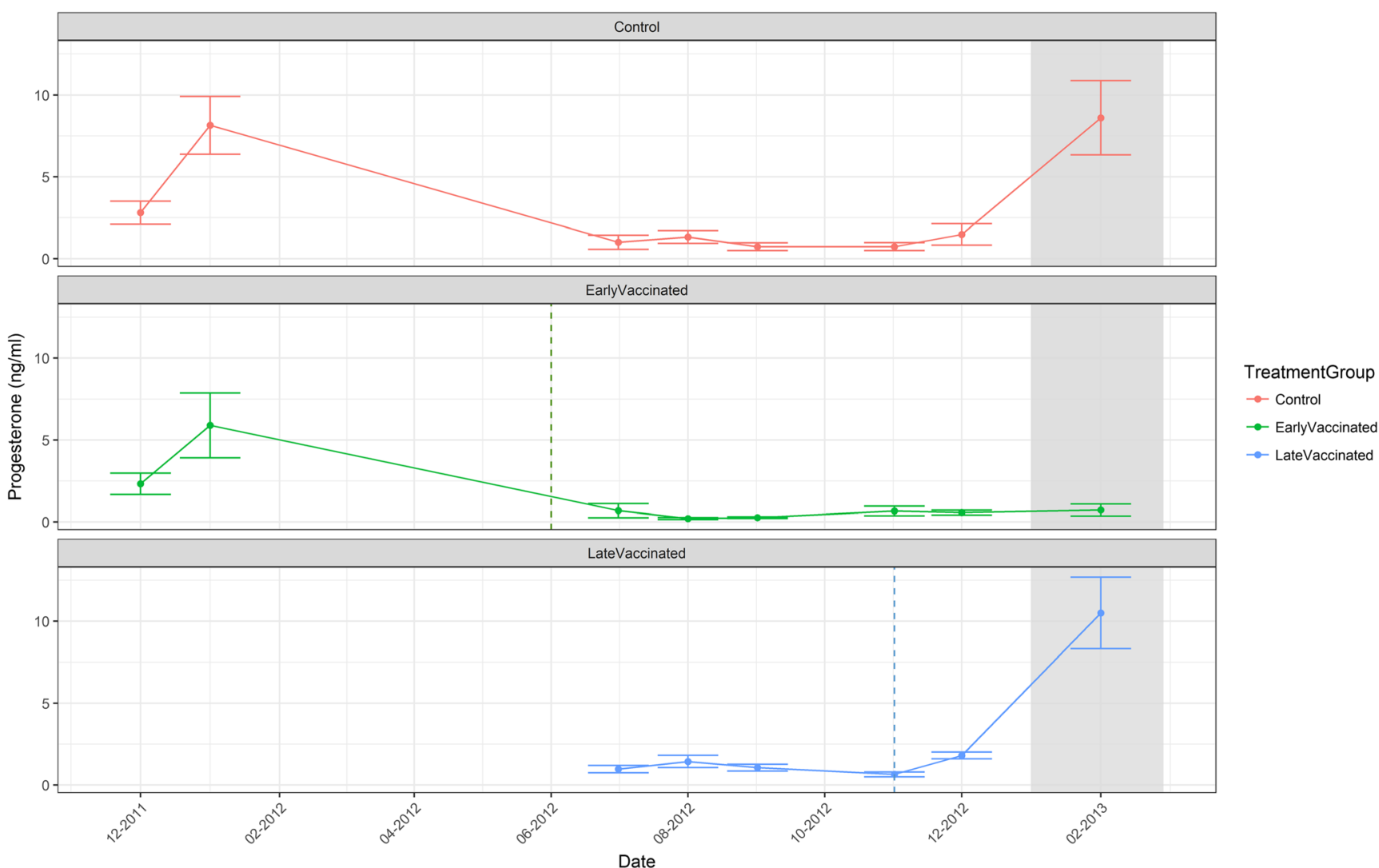

Fig. 3 Variation in mean $( \pm \mathrm{SE})$ serum progesterone levels $(\mathrm{ng} / \mathrm{mL})$ for females in the early vaccination, late vaccination and control groups. The dashed lines mark the dates for the early vaccination (green-June 2012)

and the late vaccination (blue-Nov 2012) with GonaCon. The grey shading delimits the time period of interest for comparison between the experimental groups

employed to ensure emotional and physical enrichment through feeding.

\section{Study design and treatments}

Initially, 20 adult females were allocated to three treatment groups: early vaccination $(n=7)$, late vaccination $(n=7)$ and control (unvaccinated, $n=6$ ). The terms "early" and "late" reflect the approximate earliest and latest times of year when application in the field could occur under the current UK close season (December to May) for licenced badger trapping. Each individual in the early vaccination group was treated in the first week of June whilst the late vaccination group was treated in the first week of November 2012. In both cases, each individual received a single $1-\mathrm{mL}$ dose containing $1000 \mu \mathrm{g}$ of GonaCon. The vaccine was administered by deep intra muscular injection into the quadriceps femoris muscle, approximately $1 \mathrm{~cm}$ anterior to the mid shaft of the femur. The same batch of GonaCon was used for both treatment groups (6month storage is approved under the current EPA registration for GonaCon). Additional animals were recruited to the control group which consequently increased in size (to $n=10$ ) during the study. Post-vaccination, the animals were closely monitored for any side effects (defined as anything untoward found during veterinary examinations or observed by animal care staff) over the duration of the study (June 2012 to November 2015).

Twenty males were randomly allocated to a "Vaccinated" group ( $n=11)$ or a "Control" group $(n=9)$, with the former receiving an intramuscular injection of a single 1-mL dose containing $1000 \mu \mathrm{g}$ of GonaCon in June 2014.

\section{Monitoring of physiology and fertility}

All females were anesthetised every 4-5 weeks between June and February each year of the study (2012, 2013 and 2014), except for January 2013, 2014 and 2015 and December 2014 due to concerns about anaesthetising torpid badgers during periods of relatively low ambient temperatures. All males were anaesthetized once per month between August and November 2014 and in March 2015. Badgers were anaesthetised intramuscularly, either in the hind limb or para-lumbar musculature, using the anaesthetic described in De Leeuw et al. (2004).

At each examination, individuals were weighed and health checked, and a sample of blood was collected from every animal and then centrifuged to separate and freeze the serum. 


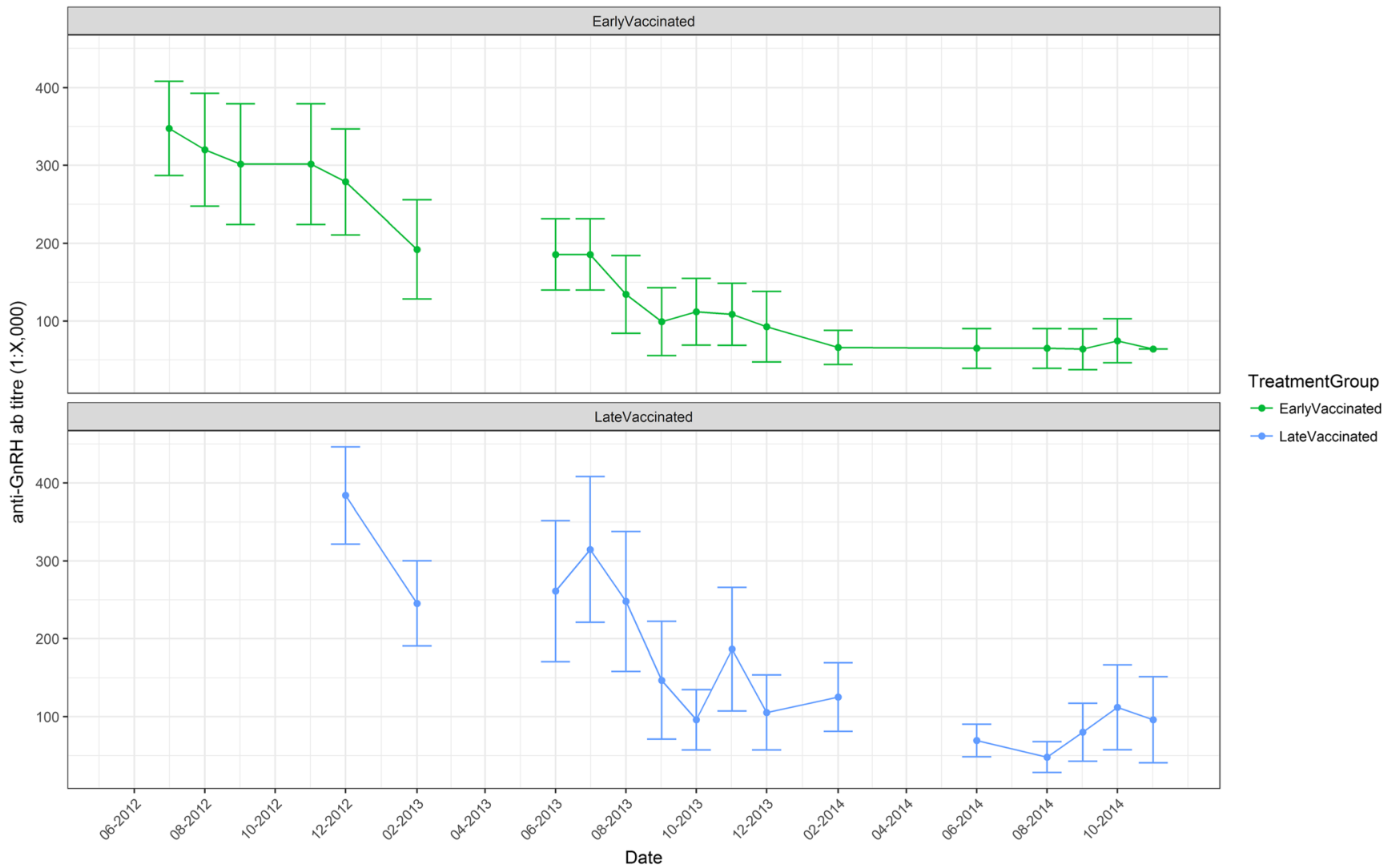

Fig. 4 Variation in mean $( \pm$ SE) anti-GnRH antibody titres in the early (green-June 2012) and late (blue-Nov 2012) vaccination groups

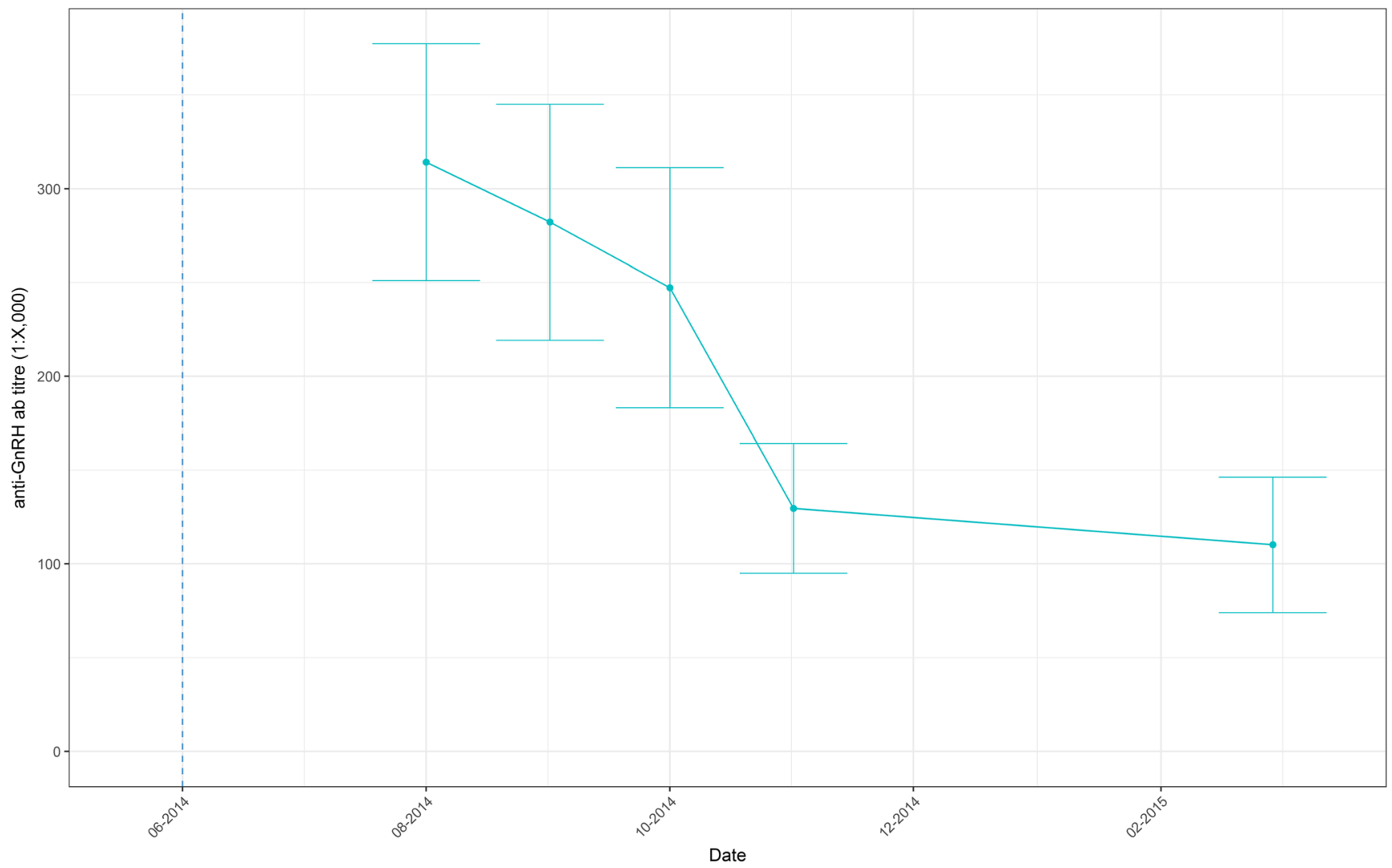

Fig. 5 Variation in mean $( \pm \mathrm{SE})$ anti-GnRH antibody titres in males after vaccination with GonaCon 
Table 1 Summary of anti-GnRH antibody titre levels in vaccinated females that produced litters, and those that did not, over the course of three reproductive cycles

\begin{tabular}{|c|c|c|c|c|c|c|c|}
\hline \multicolumn{2}{|c|}{$\begin{array}{c}\text { 2013- Early } \\
\text { vaccination group }\end{array}$} & \multicolumn{2}{|c|}{$\begin{array}{l}\text { 2013- Late vaccination } \\
\text { group }\end{array}$} & \multicolumn{2}{|c|}{ 2014- Vaccinated group } & \multicolumn{2}{|c|}{ 2015- Vaccinated group } \\
\hline $\begin{array}{l}\text { Number } \\
\text { of } \\
\text { females } \\
\text { that } \\
\text { littered }\end{array}$ & $\begin{array}{l}\text { Number } \\
\text { of females } \\
\text { that did } \\
\text { not litter }\end{array}$ & $\begin{array}{l}\text { Number } \\
\text { of females } \\
\text { that } \\
\text { littered }\end{array}$ & $\begin{array}{l}\text { Number } \\
\text { of females } \\
\text { that did } \\
\text { not litter }\end{array}$ & $\begin{array}{l}\text { Number of } \\
\text { vaccinated } \\
\text { females that } \\
\text { littered }\end{array}$ & $\begin{array}{l}\text { Number of } \\
\text { vaccinated } \\
\text { females that } \\
\text { did not litter }\end{array}$ & $\begin{array}{l}\text { Number of } \\
\text { vaccinated } \\
\text { females that } \\
\text { littered }\end{array}$ & $\begin{array}{l}\text { Number of } \\
\text { vaccinated } \\
\text { females that } \\
\text { did not litter }\end{array}$ \\
\hline 0 & 6 & 6 & 1 & 3 & 7 & 3 & 7 \\
\hline $\begin{array}{l}\text { Titres* of } \\
\text { females } \\
\text { that have } \\
\text { littered }\end{array}$ & $\begin{array}{l}\text { Titres* of } \\
\text { females } \\
\text { that did } \\
\text { not litter }\end{array}$ & $\begin{array}{l}\text { Titres* of } \\
\text { females } \\
\text { that have } \\
\text { littered }\end{array}$ & $\begin{array}{l}\text { Titres* of } \\
\text { females } \\
\text { that did } \\
\text { not litter }\end{array}$ & $\begin{array}{l}\text { Titres* of } \\
\text { females that } \\
\text { have littered }\end{array}$ & $\begin{array}{l}\text { Titres* of } \\
\text { females that } \\
\text { did not litter }\end{array}$ & $\begin{array}{l}\text { Titres* of } \\
\text { females that } \\
\text { have littered }\end{array}$ & $\begin{array}{l}\text { Titres* of } \\
\text { females that } \\
\text { did not litter }\end{array}$ \\
\hline NA & $\begin{array}{l}1 \text { female } \\
1: 32,000 \\
2 \text { females } \\
1: 128,00 \\
2 \text { females } \\
1: 256,000 \\
1 \text { female } \\
1: 512,000\end{array}$ & $\begin{array}{l}2 \text { females } \\
1: 32,000 \\
\\
3 \text { females } \\
1: 256,000 \\
\\
1 \text { female } \\
1: 512,000\end{array}$ & $\begin{array}{l}1 \text { female } \\
1: 512,000\end{array}$ & $\begin{array}{l}1 \text { female } \\
1: 8,000 \\
1 \text { female } \\
1: 16,000 \\
1 \text { female } \\
1 ; 64,000\end{array}$ & $\begin{array}{l}1 \text { female } \\
1: 32,000 \\
2 \text { females } \\
1: 64,000 \\
2 \text { females } \\
1: 128,00 \\
\\
2 \text { females } \\
1: 256,000\end{array}$ & $\begin{array}{l}1 \text { females } \\
1: 64,000 \\
2 \text { females } \\
1: 512,000\end{array}$ & $\begin{array}{l}1 \text { female no } \\
\text { detectable } \\
\text { titres } \\
2 \text { females } \\
1: 8,000 \\
2 \text { females } \\
1: 32,000 \\
1 \text { female } \\
1: 256,000 \\
1 \text { female } \\
1: 512,000\end{array}$ \\
\hline
\end{tabular}

Measured in February when pregnancy status of females could be ascertained by ultrasound

\# These females had been revaccinated in September 2014 when their previous titre levels had fallen to 1:32,000

The area around the injection sites of each vaccinated individual was palpated. Progesterone and cortisol (as a measure of physiological stress) levels in female blood serum samples were measured by ELISA using validated kits (DX-EIA-1561 Progesterone 96 Well, DX-EIA1887 Cortisol 96 Well, Immunodiagnosticsystems Ltd., UK), while blood samples from males were analysed for testosterone concentration (protocol described in Buesching et al. (2009)). Anti-GnRH antibody titres in all spun blood serum samples were quantified using an indirect ELISA technique based on that described by Miller et al. (2000), Levy et al. (2004) and Bender et al. (2009) and specifically adapted for the badger as described in Supplementary Information file 1. The titres are reported as the highest 1:X,000 dilution at which antibodies were detected.

Testicular status of males was assessed as described by Woodroffe and Macdonald (1995). Ultrasound examination of anaesthetised female badgers was undertaken to assess and measure reproductive structures (cervix, uterine body and bifurcation into the left and right uterine horns). The presence of embryos (early postimplantation with head indistinct from body) and foetuses (head and body distinct and measurable with ossification sometimes apparent) was noted. Examples of ultrasound imaging can be found in Supplementary Information 2 . Five variables were considered to be indicators of fertility in female badgers as follows: 


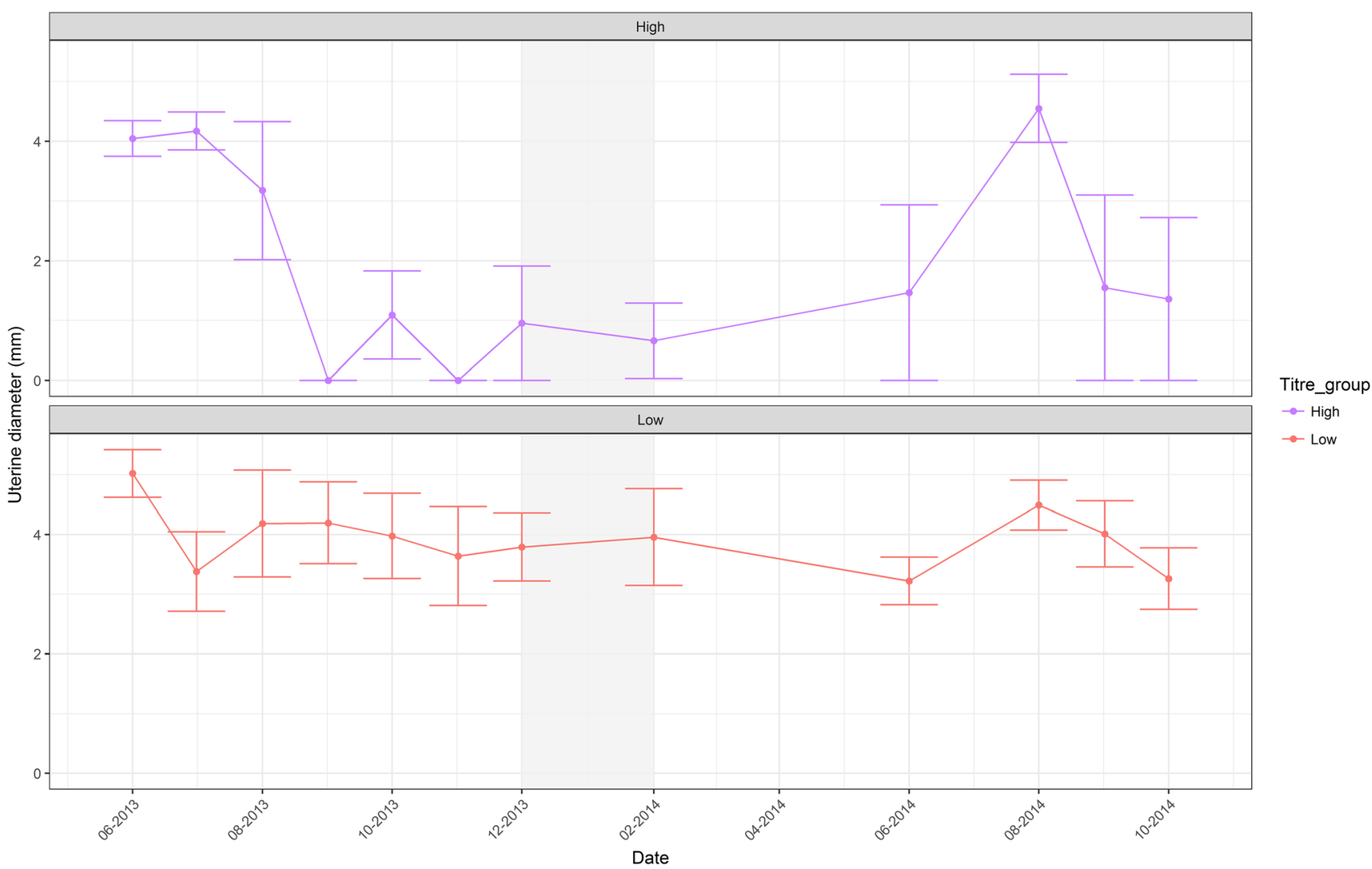

Fig. 6 Variation in mean $( \pm \mathrm{SE})$ uterine diameter $(\mathrm{mm})$ in females with high $(1: 128,000$ and above) and low (1:64,000 and below) titres. The grey shading delimits the time period of interest for comparison between the experimental groups

(a) the presence of one or more blastocysts during any ultrasound observation undertaken between June and December (peak dates for blastocysts).

(b) uterine diameter between December and February (peak dates for pregnancy-)

(c) progesterone serum level greater than $7 \mathrm{ng} / \mathrm{mL}$ in a February blood serum sample.

(d) one or more embryos or foetuses present at a February ultrasound examination.

(e) litter known to have been produced in February or March (peak dates for birth)

\section{Statistical analyses}

In order to evaluate the consequences of delayed implantation and timing of vaccination on the effectiveness of GonaCon in inducing infertility in the following breeding season (i.e. up to March 2013), female fertility indicators were in a first instance compared between (A) the control group and the early vaccination group and $(\mathrm{B})$ the control group and the late vaccination group. Post-March 2013, the early vaccination and late vaccination female groups were pooled together for analysis.

Proportions between treatment groups (e.g. proportion of female with embryos, with $>1$ blastocysts ...) were compared using Fisher's exact test. A two-sample $t$ test was used to compare the means of normally distributed continuous variables (body weight) between the vaccinated and the control groups. A Mann-Whitney $U$ test was used for non-normally distributed continuous variables (uterine diameter, testosterone, testis status index). $P$ values were adjusted for multiple comparisons, when appropriate, by controlling the false discovery rate as proposed by Benjamini and Hochberg (1995). Given the small sample sizes in this study, we expect the power of the statistical tests (defined as the probability of rejecting the null hypothesis - of no difference between the treatment groups - when it is in fact wrong) to be very low. As such, our results should be interpreted with the necessary caution.

As initial data exploration provided anecdotal evidence of a putative titre fertility threshold of GonaCon of 1:128,000 (see results), we further investigated the effect of titre levels on the various fertility indicators in the longer term (i.e. post March 2013) by comparing females with high titre levels (1:128,000 and above) to females with low titre levels (1:64,000 and below). To evaluate the longevity of the female infertility induced by GonaCon, the time between vaccination and the second consecutive anti-GnRH antibody titre assay reading below 1:128,000 was used to fit a Cox proportionalhazards model (Cox 1972) to (A) investigate the association 


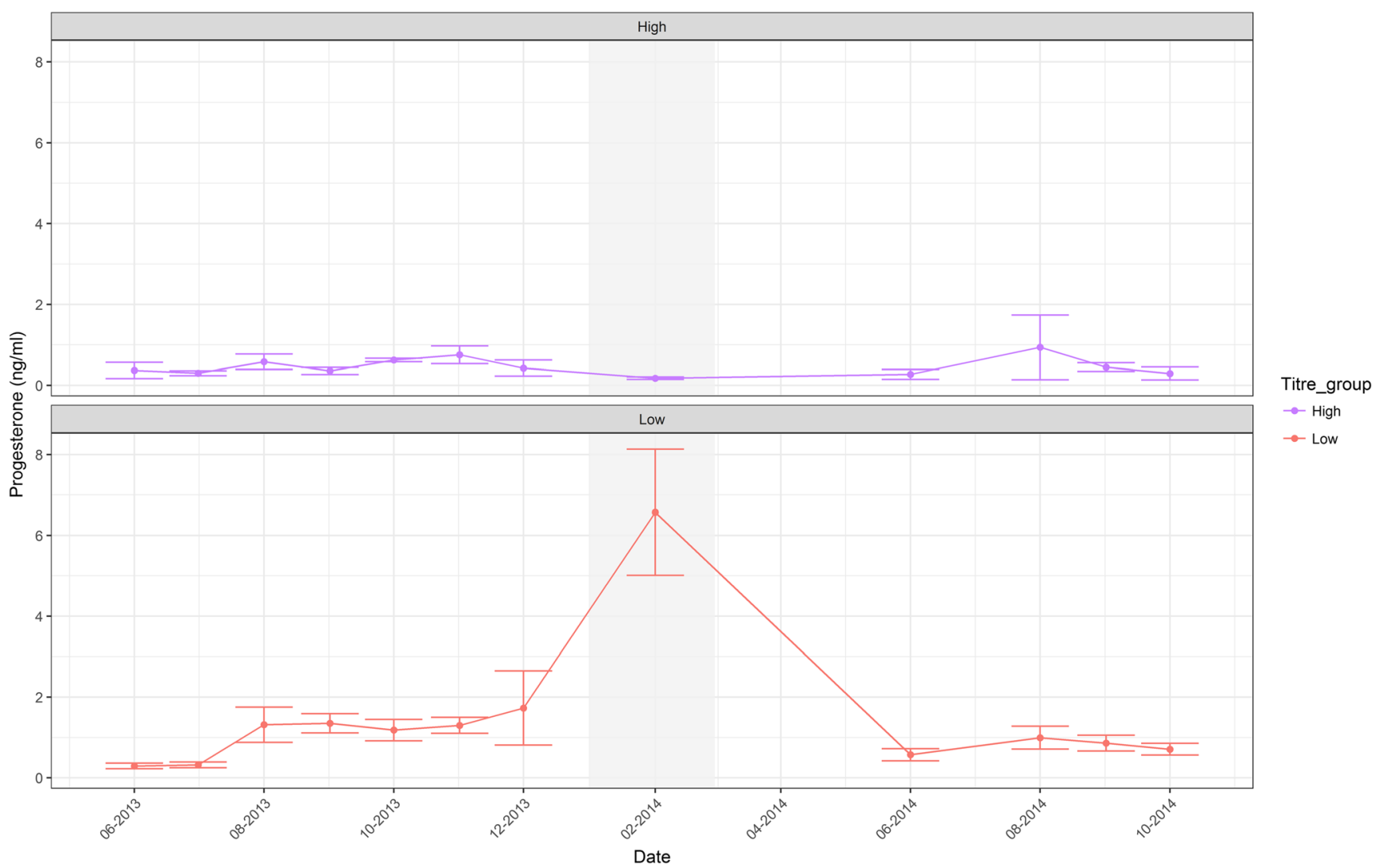

Fig. 7 Variation in mean $( \pm \mathrm{SE})$ serum progesterone levels $(\mathrm{ng} / \mathrm{mL})$ for females in females with high $(1: 128,000$ and above $)$ and low $(1: 64,000$ and below) titres. The grey shading delimits the time period of interest for comparison between the experimental groups

between the time to reaching the putative titre fertility threshold and the timing of vaccination (early vs. late vaccination groups) and (B) determine the median time taken for titres in females to fall below this threshold.

All analyses and figures were produced in R ( $\mathrm{R}$ Core Team 2017) using the following packages: here (Müller 2017), ggplot2 (Hadley Wickham 2009), dplyr (Hadley Wickham et al. 2017), scales (Hadley Wickham 2017), survival (Therneau 2015), survminer (Kassambara and Kosinski 2018), tidyr (Hadley Wickham and Henry 2017) and zoo (Zeileis and Grothendieck 2005).

\section{Results}

\section{Effects of delayed implantation on the effectiveness of GonaCon in inducing female infertility the following breeding season}

No blastocysts were identified in any females in the early vaccination group during 2012 (Fig. 1). One month post-vaccination, 2/7 females in the late vaccinated group showed signs of blastocysts, compared to $3 / 6$ females in the control group (Fisher's exact $p>0.99$ ).
There was a statistically significant difference in uterine diameter between the control $(n=6)$ and the early vaccinated groups $(n=7)$ in July $2012(W=35$, adj. $p=0.02)$ (Fig. 2). Differences in August, September and November 2012 although non-significant were borderline $(0.05<$ adj. $p<0.07)$. However, we found no statistically significant difference in uterine diameter between the two groups in December 2012 $(W=25$, adj. $p=0.59)$ or February 2013 ( $W=29$, adj. $p=$ 0.13 ) which should represent peak pregnancy months. Similarly, there was no statistically significant differences in uterine diameter between the control $(n=6)$ and late vaccination $(n=7)$ groups in December $2012(W=17.5$, adj. $p=$ 0.87), February 2013 ( $W=22$, adj. $p=0.95$ ) or other time points up to March 2013 (all adjusted $p$ values $>0.27$ ).

Progesterone levels were higher in the control group compared to the early vaccinated group in August 2012 ( $W=41$, adj. $p=0.04$ ), but no difference was found for all other time points (all adj. $p>0.17$, Fig. 3). No differences in progesterone levels between the control and late vaccinated groups were detected throughout the entire period leading up to March 2013 (all adj. $p>0.30$ ).

No embryos or foetuses were identified in any females in the early vaccination group in February 2013. Embryos/ foetuses were identified in $2 / 7$ females in the late vaccination group in February 2013 (3 months post-vaccination) and in 3/ 
Strata + Early vaccinated + Late vaccinated

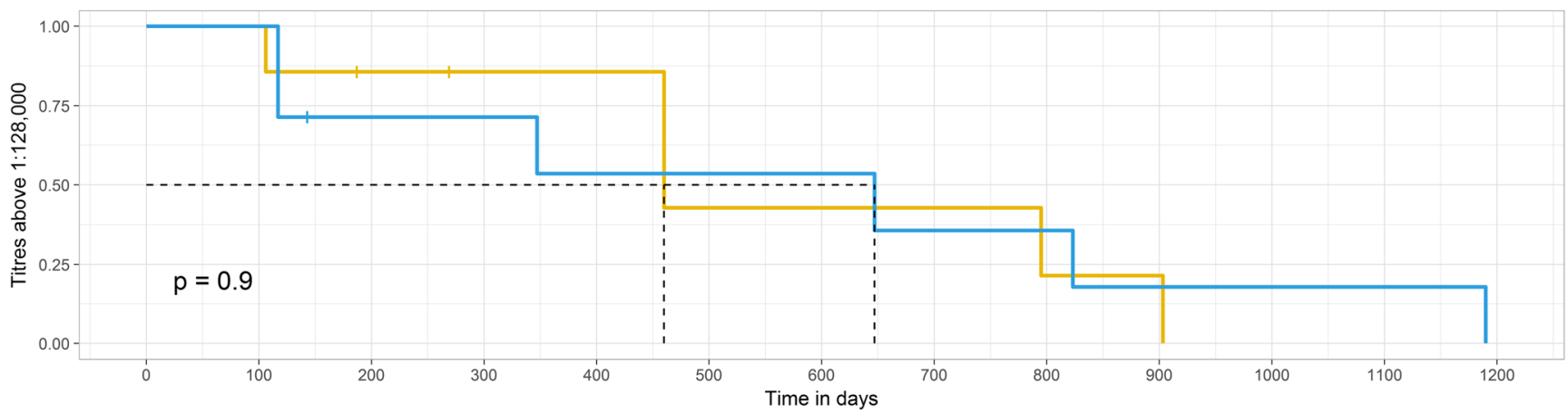

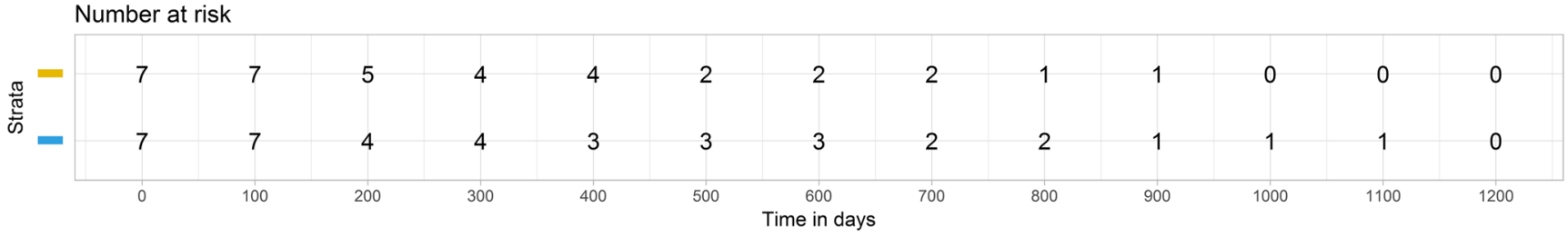

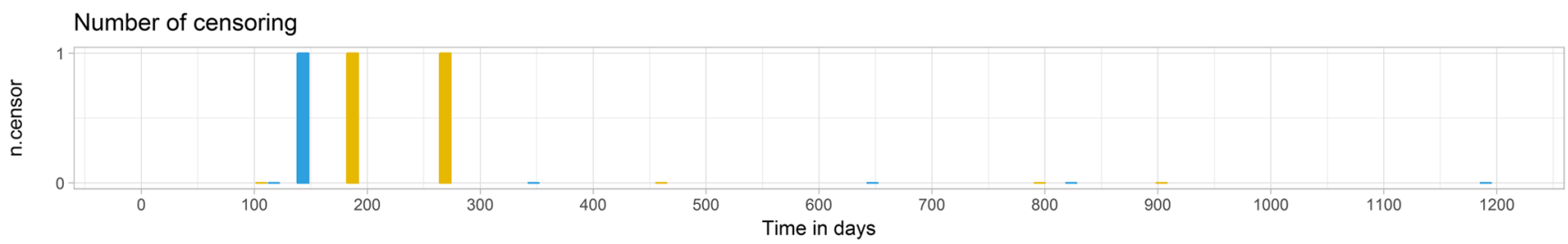

Fig. 8 Survival curves based on Kaplan-Meier estimates of the time between vaccination and two consecutive anti-GnRH assay titre readings below the putative fertility threshold of $1 ; 128,000$. The number of

6 control females (3/6) (Fisher's exact $p=0.59)$. None of the six surviving individuals in the early vaccination group (one female died under anaesthesia in December 2012) gave birth in February or March 2013. However, litters were born in February or March 2013 to 6/7 females in the late vaccination group, compared to $3 / 6$ control females (Fisher's exact $p=$ $0.27)$.

\section{Anti-GnRH antibody titres and longevity of reduced fecundity}

All females in both the early and late vaccination groups (and none, as expected, in the control group) expressed anti-GnRh antibody titres 1 month after vaccination. In two females (one in the early and one in the late vaccination group), titres quickly decreased from 1:256,000 1 month post-vaccination to $1: 64,000$ and 1:32,000, respectively, within 2 months. In all other individuals, the titres gradually declined (Fig. 4) to the extent that by February 2013 ( 8 months post-vaccination and 3 months post-vaccination for the early and late vaccination groups, respectively), 1/6 early vaccination group females and $2 / 7$ in the late vaccination group had titres below 1:64,000, threshold below which fertility is compromised in other species such as wild boar and white-tailed deer (L. A. Miller et al. 2008; Massei et al. 2012). censoring represents females that died over the course of the study and for which the last reading gave titre levels of 1:128,000 or above

Nine out of the 10 males vaccinated had measurable antiGnRH antibody titres 2 months later. However, one individual showed no response at any time after vaccination. The mean titres declined with time post-vaccination (Fig. 5) but were still apparent in March 2015 (9 months post-vaccination) for the other nine males, at which time six had titres of at least $1: 64,000$.

In 2013, none of the six early vaccination females littered, with five individuals showing titres of 1:128,000 and above in February 2013, month of the ultrasound that ascertained that some of (treated and control) females were pregnant (Table 1). The sixth female did not litter despite low levels of titres. Interestingly, four of the six late vaccination females that littered in 2013 had titres of 1:256,000 and above in February 2013, suggesting that vaccination in November may be too late into the reproductive cycle to induce immediate infertility.

By 2014, a further three vaccinated females had died (two from the early and one from the late vaccination groups). Post mortem examinations did not indicate any causes of death attributable to GonaCon vaccination. The February antiGnRH antibody titres of the three vaccinated females that produced litters that year were in all cases equal or inferior to $1: 64,000$ (Table 1). Four of the seven vaccinated females that did not produce a litter in 2014 had titres of 1:128,000 and 


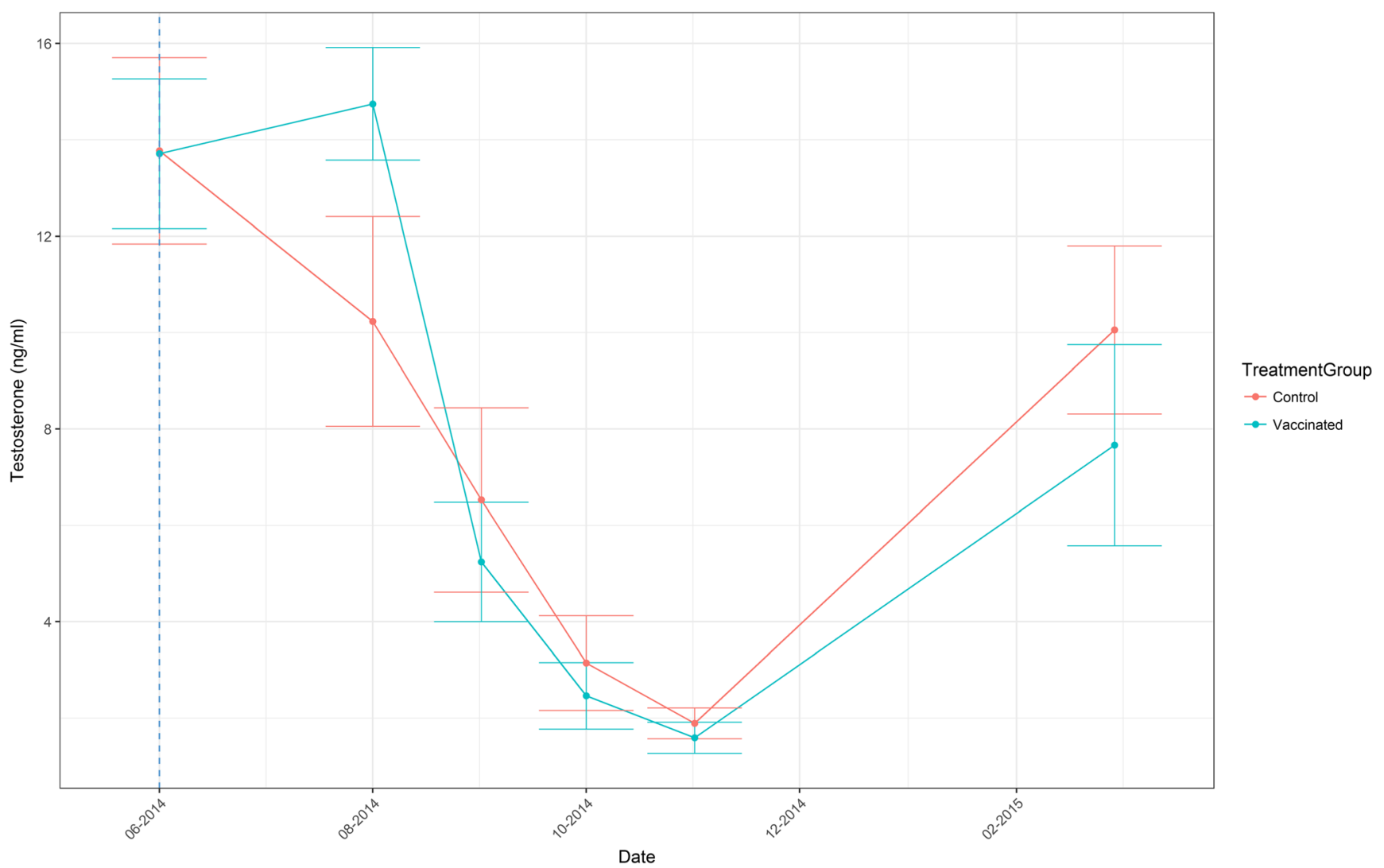

Fig. 9 Variation in mean $( \pm \mathrm{SE})$ serum testosterone levels $(\mathrm{ng} / \mathrm{mL})$ for males in the vaccinated and control groups. The dashed line marks the date of the vaccination (June 2014) with GonaCon

above, while three showed titres of 1:64,000 and below. A similar pattern was found in 2015 with only two of the seven vaccinated females that did not produce a litter that year showing titres of 1:128,000 and above. The situation in 2015 is compounded by the fact that three females with titre levels of 1:32,000 or below were revaccinated mid-September 2014. Despite all three subsequently showing high $(1: 512,000)$ levels of titres 1 month post-vaccination, two of these females produced litters in 2015, further suggesting that the time window to administer the vaccine and successfully induce infertility in the following year could be as narrow as June-August. If we leave the revaccinated individuals aside, no treated female badgers with titres above $1: 128,000$ produced a litter over the 3 years of the study, suggesting that the putative fertility threshold for GonaCon in badgers may be higher (titre levels above 1:128,000) than that observed in other mammalian species.

Further anecdotal evidence of a putative 1:128,000 antiGnRH antibody titre threshold for fertility is found by considering other indicators. For example, $0 / 4$ females with high titres (1:128,000 and above) showed observable embryos/ foetuses during ultrasounds carried out in February 2014, compared to $3 / 6$ females with lower titres (1:64,000 and below). Difference in median uterine diameter between females with high and with low titres were borderline significant in
September 2013 ( $W=9$ adj. $p=0.054)$, December $2013(W=$ 14 adj. $p=0.054)$ and February $2014(W=17.5$ adj. $p=0.07)$ (Fig. 6). Progesterone levels were higher in females with low titres compared to those with high titres (Fig. 7) in September $2013(W=6, p=0.017)$ and in February $2014(W=5, p=$ $0.003)$.

The timing of vaccination (early June or late November) had no significant effect (Wald test $p=0.88$ ) on the longevity of the response as measured by the time to two consecutive titre readings below 1:128,000 (Fig. 8). When both early and late vaccination groups were combined, the median longevity (as defined above) was 647 days.

\section{Monitoring of possible side effects of GonaCon injection in male and female badgers}

We observed no difference in testosterone levels (Fig. 9, all adj. $p>0.99$ ) between vaccinated and control males throughout their follow-up post-vaccination in June 2014. Although the mean testis status index of vaccinated males appeared to decline more markedly in vaccinated males, relative to that of controls males, during autumn and winter (Fig. 10), we found no statistically significant difference in testis status index throughout the follow-up period (all adj. $p$ values $>0.12$ ). 


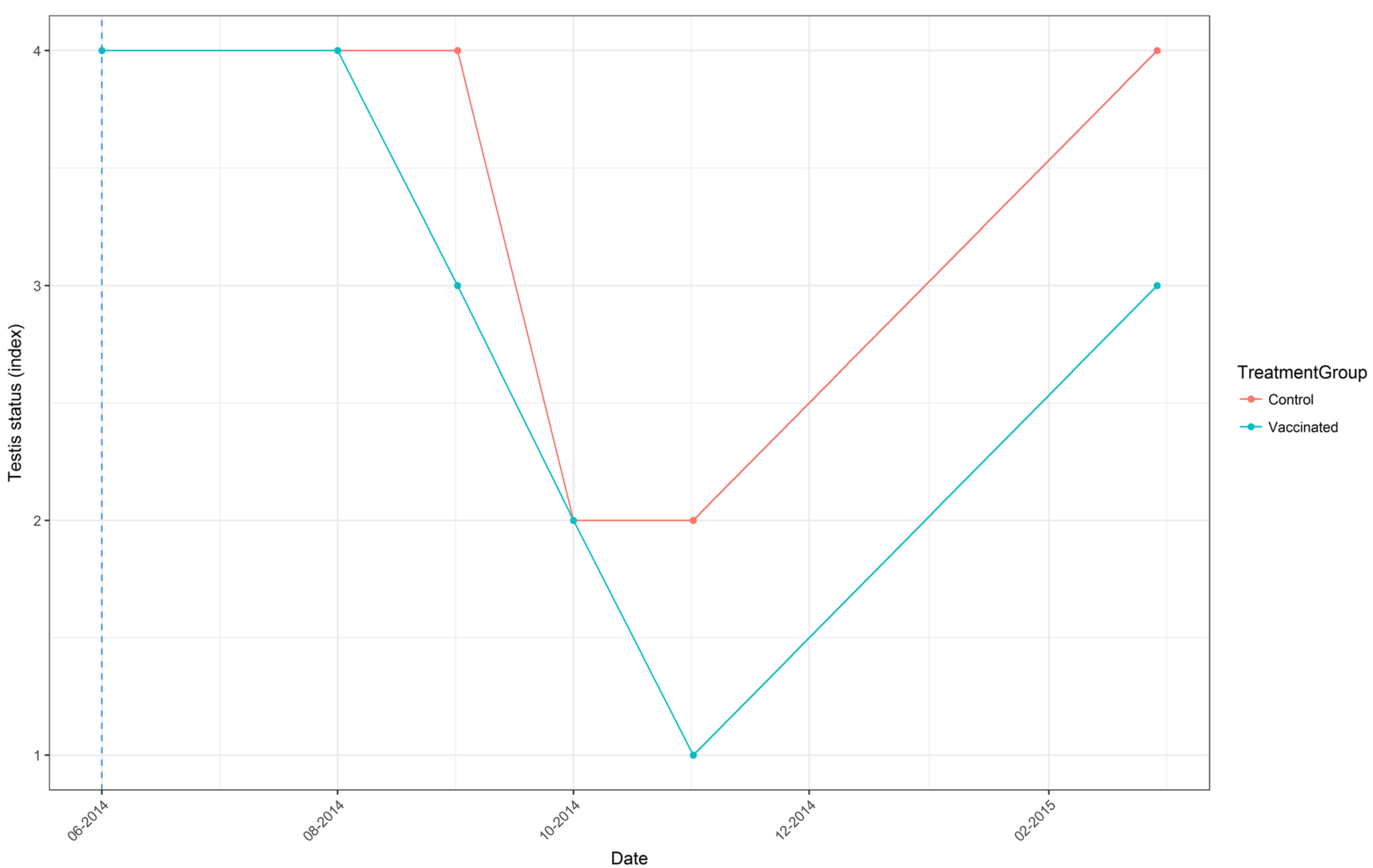

Fig. 10 Variation in median testis status index for males in the vaccinated and control groups. The dashed line marks the date of the vaccination (June 2014) with GonaCon

Apart from transient lameness in some animals, no side effects were noted. We found no statistically significant differences in cortisol levels between the control and the early vaccinated groups (all adj. $p>0.67$ ) in the two samples taken prior to injection and during the 2 months post-treatment. A similar pattern was found when comparing the control and late vaccination group (all adj. $p>0.99$ ) (Fig. 11). We also found no statistically significant differences in the body weight of females (all adj. $p>0.77$, Fig. 12) and males (Fig. 13, all adj. $p>0.17)$ between the control and the vaccinated groups throughout the entire period under study.

\section{Discussion}

At approximately 1 month after vaccination all treated females had anti-GnRH antibody titres greater than those typically associated with reduced fertility in other species (L. A. Miller et al. 2008; Gray et al. 2010; Massei et al. 2012). These other fertility control studies will, in some cases, have used species-specific agents and slightly different methodologies to read titre levels although we do not expect those to affect the relative sensitivities of the assays. The rapid onset of titres and the effect on reproductive physiology were reflected in the relatively small uterine diameter of the early vaccination group in July 2012, 1 month after their vaccination. In contrast, the uterine diameters in the control group were highest at this time which is consistent with descriptions of the uterine endometrium assuming a secretory appearance from this time (Bonnin-Laffargue 1964). It is possible that absence of this function in the early vaccinated individuals, as a consequence of the June vaccinations, would have compromised subsequent maintenance of blastocysts.

The novel use of ultrasound to monitor pre-implantation reproductive physiology in the badger extended to the successful recognition of blastocysts. However, it was only possible to observe by ultrasound approximately two-thirds of the uterine tract, with the rest being obscured by other tissues. Hence, the numbers of blastocysts detected will have underestimated the actual numbers present. Nevertheless, some blastocysts were detected in at least some of the control and late vaccination groups at each of the five sampling points between July and December 2012 while, in contrast, no blastocysts were found in any of the early vaccination group during this period. This suggested that either inhibition of blastocyst production and/or maintenance of blastocyst during this period occurred in the early vaccination group. The immediate effect of vaccination on productivity was confirmed by the absence of litters in the early vaccination group in the following February or March, compared to confirmed litters born to 


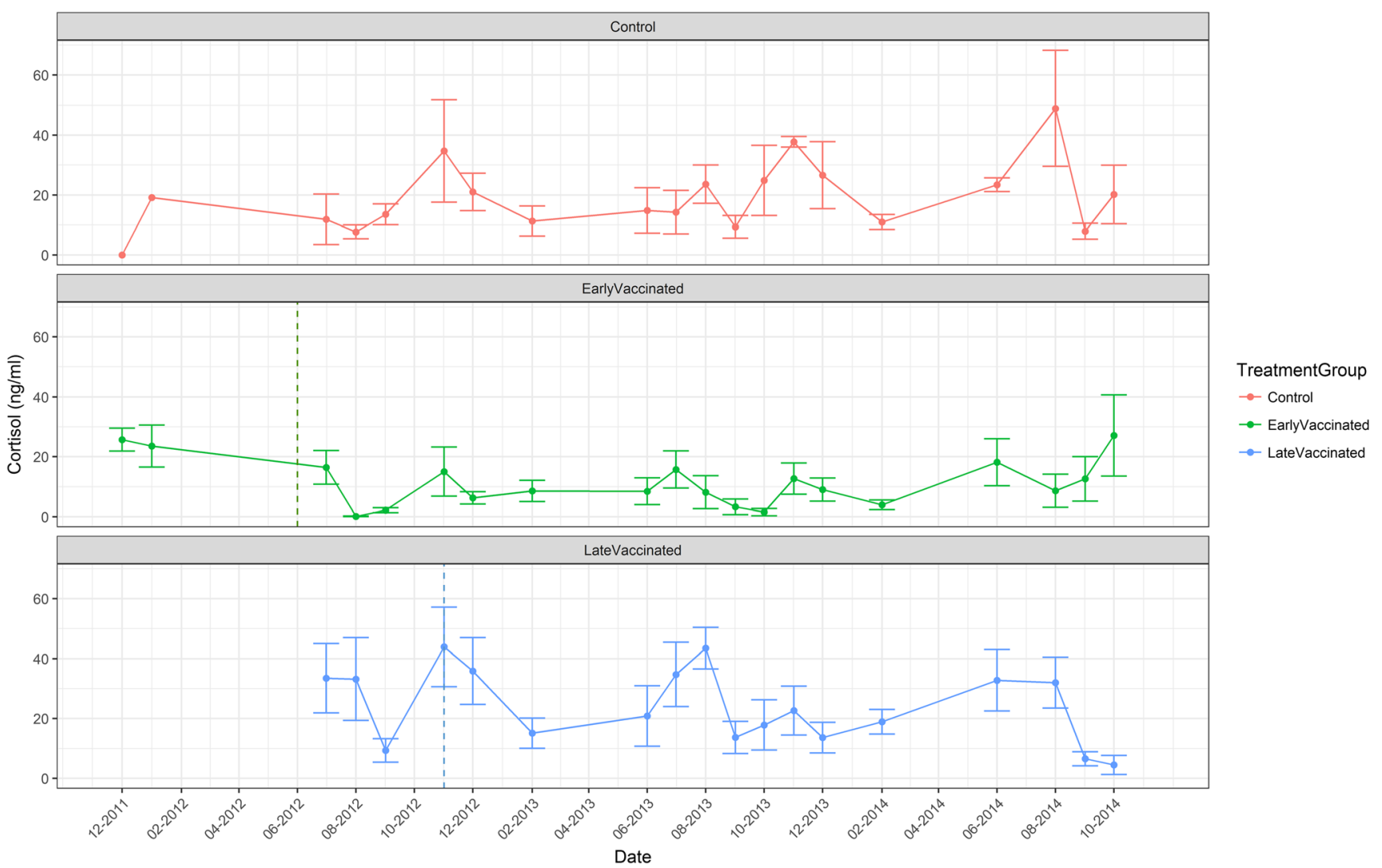

Fig. 11 Variation in mean $( \pm \mathrm{SE})$ serum cortisol levels $(\mathrm{ng} / \mathrm{mL})$ for females in the early vaccination, late vaccination and control groups. The dashed lines mark the dates for the early vaccination (green-June 2012) and the late vaccination (blue-Nov 2012) with GonaCon

six out of the seven late vaccination group females and three out the six unvaccinated group females. We concluded that early vaccination had an immediate effect and inhibited subsequent cub production, despite the potential for delayed implantation of any pre-existing fertilised blastocysts, but the late vaccination did not.

The higher progesterone levels observed in control females in August 2012, relative to the early vaccination group, are consistent with the biphasic seasonal variation in progesterone levels in badgers described by Bonnin et al. (1978). This modest rise in progesterone during the summer has been suggested to be of ovarian origin because of the increase in luteal size and progesterone content observed in September by Canivenc et al. (1966). It is thus probable that this rise in progesterone could be affected by targeting GnRH with GonaCon and, hence, the immediate negative effect on reproduction brought about by the June vaccinations. However, the absence of an immediate effect of the November vaccinations on reproduction in the late vaccination group indicates that the second phase of progesterone increase, beginning just prior to implantation, was not affected by inhibiting the GnRH. Canivenc and Bonnin (1981) describe a process of luteal reactivation from October through to December associated with increases in the size and progesterone content of badger luteal tissue and this reactivation is associated with increasing luteinising hormone (LH) levels during this period. Furthermore, LH levels are raised more by ovariectomy in October than in April, indicating that the pituitary is more sensitive to declines in circulating ovarian products towards the end of the period of delayed implantation. What influences such sensitivity is unclear. However, Bonnin et al. (1984) describe a highaffinity binding protein, specifically corticosteroid binding globulin $(\mathrm{CBG})$, present in badger plasma whose level is substantially raised in September which they suggest might involve a pituitary factor. Such a factor will not necessarily be regulated by GnRH and thus may not be amenable to manipulation by a vaccine targeting this hormone. Hence, once the process involving such a factor is underway this will lead inexorably to the implantation of existing blastocysts, and vaccination in November will thus be too late to inhibit cub production. We also observed that a second vaccination of three females in September 2014 failed to prevent litter production in 2015 and, hence, was already too late for immediate effectiveness. If the rise in $\mathrm{CBG}$ in September is an indicator of the initiation of a process that is mediated by GnRH then it is possible that 


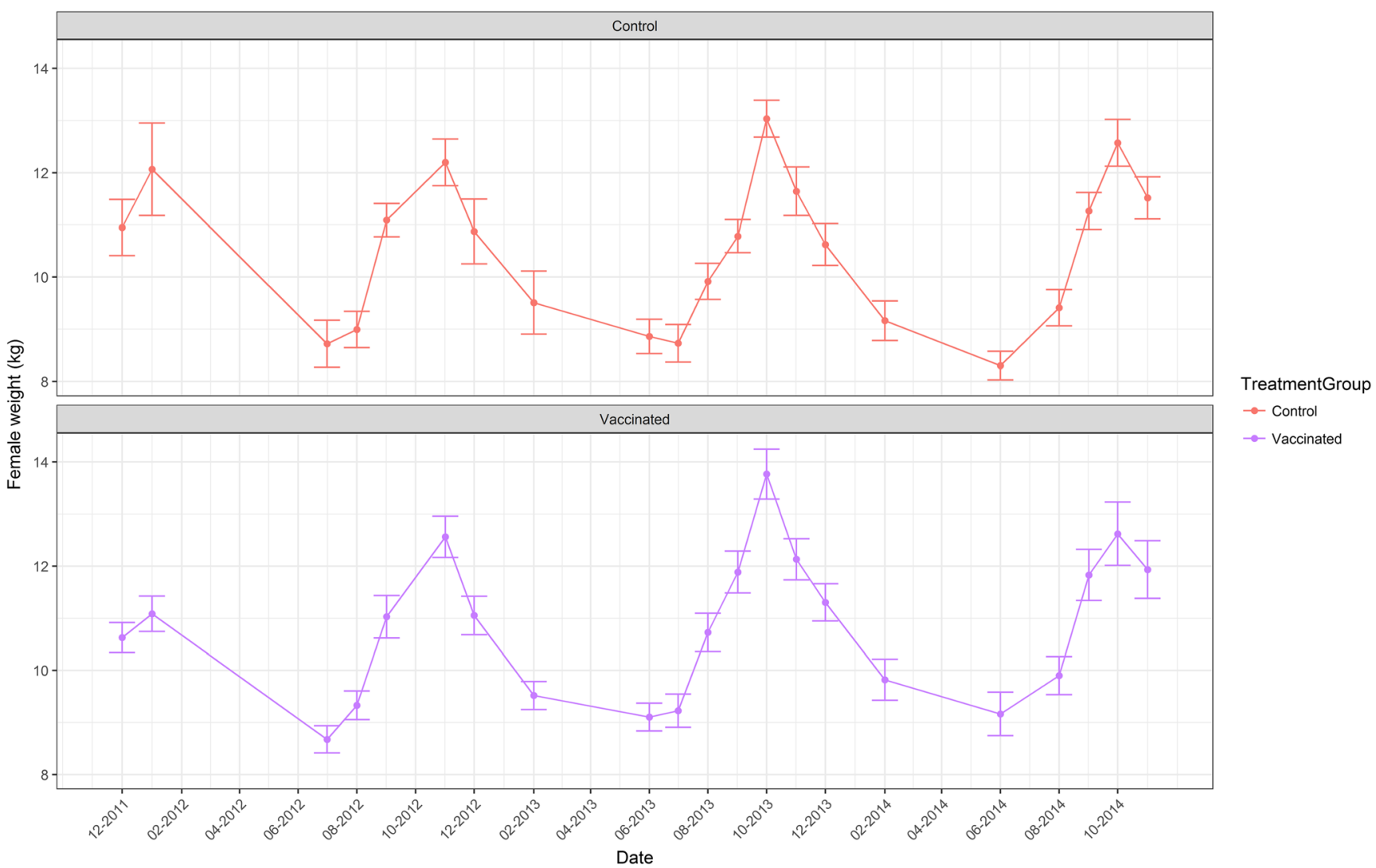

Fig. 12 Variation in mean body weights $( \pm$ SE) of females in the vaccinated and control groups

vaccination prior to this onset might have an immediate effect on subsequent cub production. The effective vaccination period, given the existing close season on badger trapping, may thus be between June and August.

The longer-term effectiveness of GonaCon vaccination in female badgers appears to reflect maintenance of anti-GnRH antibody titres at or above a putative threshold titre of $1: 128,000$. Furthermore, by the end of the third postvaccination breeding season, there was no evidence of any effects on overall fertility with only one out of four vaccinated females having anti-GnRH antibody titres above the putative infertility threshold. Hence, although the initial strength and frequency of immune responses to GonaCon were comparable to those seen in other species, the maintenance of titres at or above the threshold was shorter. Variation between individuals in the longevity of responses to GonaCon vaccination, despite consistently high initial antibody titres, has been reported for other species, including the domestic cat (Levy et al. 2011). The reasons for this variation are unknown. The longevity of the response to GonaCon is considered to derive from the combination of a large carrier protein containing numerous $\mathrm{T}$ cell epitopes, a mineral oil emulsion and the use of an adjuvant containing M. avium (L. A. Miller et al. 2008). The granulomatous injection-site reactions frequently reported following GonaCon vaccination, typical of an adjuvanted vaccine, may be important for the generation of long-term responses. For instance, these were not found in cats with relatively short-lived responses but were found in some long-term responding individuals (Levy et al. 2011). In this context it is potentially relevant that badgers are reported to exhibit relatively modest granulomatous reactions to bTB (Gavier-Widen et al. 2001), albeit similar to those in other carnivores such as cats. It is possible that using a larger dose might lead to longer lasting effects but this would require further studies and further monitoring of potential injection site reaction. Otherwise it appears that vaccination would need to be repeated at least every 2 years in order to maintain levels of female infertility predicted to have demographic impacts on badger populations (Cowan and Massei 2008).

Overall no negative welfare consequences were observed in vaccinated female badgers. However, as Hampton et al. (2015) point out, fertility control can have many and varied welfare consequences. Further, they contend that preservation of hormonal competence is important to maximise the welfare of wild animals and thus argue against the use of endocrine suppression mechanisms, including compromising GnRH activity. On the other hand, many seasonally breeding species, including the badger, will spend significant amounts of their normal lives down-regulated with respect to reproductive endocrinology. Furthermore, such considerations need to be 


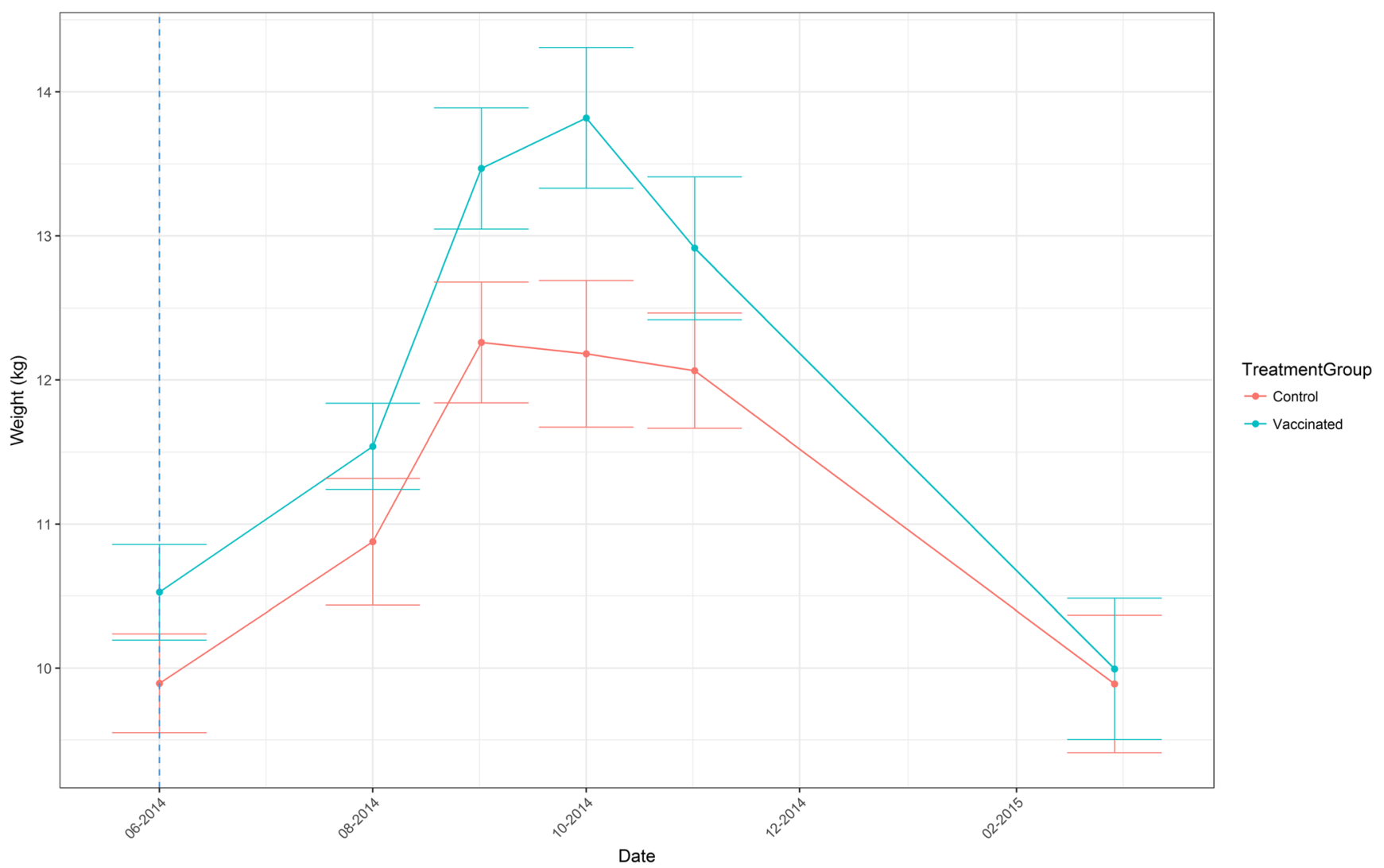

Fig. 13 Variation in mean $( \pm \mathrm{SE})$ body weight $(\mathrm{kg})$ for males in the vaccinated and control groups. The dashed line marks the date of the vaccination (June 2014) with GonaCon

compared directly with the welfare consequences of other management tools, such as culling (Kirkpatrick 2007; Massei and Cowan 2014).

We found no evidence of any immediate impact of vaccination on the fertility of males. Reducing the fertility of males is demographically less important than doing so in females. Nevertheless, in field vaccination programmes, undertaken using cage trapping without anaesthesia, it is unlikely that reliable determination of the sex of treated individuals would be feasible, so it is useful that this study has not identified any negative welfare consequences of vaccination in male badgers.

The reduction in female fertility generated by vaccination with GonaCon indicates potential as a tool for the management of conflicts involving badgers. So far, the most successful cases of demographic regulation of populations using fertility control come from applications involving small, closed populations of readily accessible species (Ransom et al. (2014b). Where culling badgers is not locally acceptable, exclusion is problematic and the conflict is substantial, the cost of applying fertility control through injection may well be the most economic answer (e.g. damage to urban structures where excluded badger would have nowhere to move to). But fertility control on its own could take a long time to suppress a population For badgers, rather than impacting large-scale demography, there is potential to complement BCG vaccination to control bTB by reducing the recruitment of new susceptible animals into vulnerable populations. BCG is currently being used as part of the UK Government strategy for bTB control and this approach may be applied much more widely if it becomes used as part of an exit strategy to the ongoing badger culling. In this scenario, the economic cost of using GonaCon would be minimal given the animals will be trapped and vaccinated anyway, and the efficacy of control could be substantially higher given that the population has already been reduced. In this situation, GonaCon would be used to reduce the rate of population recovery. Epidemiological modelling could potentially predict what proportions of individuals would need to be vaccinated to help reduce bTB prevalence. However, these predictions would still have to be tested in the field, including exploring possible effects on individual movements and social structure. For instance, Ransom et al. (2014a) observed that female horses vaccinated with a GnRh immunocontraceptive fed less, rested more, travelled less and performed more maintenance behaviours than controls, but engaged in the same amount of social behaviour. These differences were commensurate with the higher metabolic demands of pregnancy and lactation. Conversely, GonaCon did not affect social and spatial behaviour in Eastern fox squirrels (Sciurus niger (Krause et al. 2015)) and in wild boar (Massei 
et al. 2008; Quy et al. 2014). How such factors might influence the complex social structure of the badger and, in particular, interaction rates in the context of disease transmission would be important questions to address. Furthermore, possible interactions between the efficacy of the badger BCG and GonaCon vaccines would need to be evaluated, especially given potential for interaction with the M. avium adjuvant component of the GonaCon vaccine.

Acknowledgements We are grateful to the National Wildlife Research Center (United States Department of Agriculture Animal and Plant Health Inspection Service) for providing GonaCon and for useful discussions with Douglas E. Eckery on earlier drafts.

Funding information This study was financially supported by the UK Department for Environment, Food and Rural Affairs (Defra), the Scottish Government and the Welsh Government (Defra Project SE3277).

\section{Compliance with ethical standards}

Ethical statement The trapping, husbandry and care of all animals held in captivity and all procedures performed in this study were approved by the Animal Welfare Ethical Review Body (AWERB) at APHA, as required by the Animals (Scientific Procedures Act) 1986. This included necessary licences for the capture and holding of subject animals as well as ethical oversight of the regulated procedures and the scientific program. This level of care was compatible with European Directive 2010/63/EU

Open Access This article is distributed under the terms of the Creative Commons Attribution 4.0 International License (http:// creativecommons.org/licenses/by/4.0/), which permits unrestricted use, distribution, and reproduction in any medium, provided you give appropriate credit to the original author(s) and the source, provide a link to the Creative Commons license, and indicate if changes were made.

\section{References}

Bender SC, Bergman DL, Wenning KM, Miller LA, Slate D, Jackson FR, Rupprecht CE (2009) No adverse effects of simultaneous vaccination with the immunocontraceptive GonaCon and a commercial rabies vaccine on rabies virus neutralizing antibody production in dogs. Vaccine 27(51):7210-7213. https://doi.org/10.1016/j. vaccine. 2009.09.026

Benjamini Y, Hochberg Y (1995) Controlling the false discovery rate: a practical and powerful approach to multiple testing. J R Stat Soc Ser B 57:289-300

Bonnin M, Canivenc R, Ribes C (1978) Plasma progesterone levels during delayed implantation in the European badger (Meles meles). J Reprod Fertil 52(1):55-58

Bonnin M, Martin B, Charron G, Audy MC, Canivenc R (1984) C21 steroids and transcortin-type protein during delayed implantation in the European badger Meles meles L. J Steroid Biochem 20(2):575580

Bonnin-Laffargue M (1964) Contribution à l'étude de l'histophysiologie de l'appareil génital femelle du Blaireau européen (Meles meles L.). Université de Bordeaux
Brunton LA, Donnelly CA, O'Connor H, Prosser A, Ashfield S, Ashton A, Upton P, Mitchell A, Goodchild AV, Parry JE, Downs SH (2017) Assessing the effects of the first 2 years of industry-led badger culling in England on the incidence of bovine tuberculosis in cattle in 2013-2015. Ecol Evol 7(18):7213-7230. https://doi.org/10.1002/ ece3.3254

Buesching CD, Heistermann M, Macdonald DW (2009) Seasonal and inter-individual variation in testosterone levels in badgers Meles meles: evidence for the existence of two endocrinological phenotypes. J Comp Physiol A Neuroethol Sens Neural Behav Physiol 195(9):865-871. https://doi.org/10.1007/s00359-009-0465-0

Caley P, Ramsey D (2001) Estimating disease transmission in wildlife, with emphasis on leptospirosis and bovine tuberculosis in possums, and effects of fertility control. J Appl Ecol 38(6):1362-1370. https:// doi.org/10.1046/j.0021-8901.2001.00676.x

Canivenc R, Bonnin M (1979) Delayed implantation is under environmental control in the badger (Meles meles L.). Nature 278:849. https://doi.org/10.1038/278849a0

Canivenc R, Bonnin M (1981) Environmental control of delayed implantation in the European badger (Meles meles). J Reprod Fertil Suppl 29:25-33

Canivenc R, Short RV, Bonnin-Laffargue M (1966) Étude histologique et biochemique du corps jaune du blaireau européen (Meles meles L.). Ann Endocrinol 27:401-403

Carroll MJ, Singer A, Smith G, Cowan D, Massei G (2010) The use of immunocontraception to improve rabies eradication in urban dog populations

Carter SP, Delahay RJ, Smith GC, Macdonald DW, Riordan P, Etherington TR, Pimley ER, Walker NJ, Cheeseman CL (2007) Culling-induced social perturbation in Eurasian badgers $<$ em $>$ Meles meles $</$ em $>$ and the management of TB in cattle: an analysis of a critical problem in applied ecology. Proc R Soc B Biol Sci 274(1626):2769-2777. https://doi.org/10.1098/rspb.2007.0998

Chambers MA, Rogers F, Delahay RJ, Lesellier S, Ashford R, Dalley D, Gowtage S, Dave D, Palmer S, Brewer J, Crawshaw T, CliftonHadley R, Carter S, Cheeseman C, Hanks C, Murray A, Palphramand K, Pietravalle S, Smith GC, Tomlinson A, Walker NJ, Wilson GJ, Corner LAL, Rushton SP, Shirley MDF, Gettinby G, McDonald RA, Hewinson RG (2011) Bacillus Calmette-Guerin vaccination reduces the severity and progression of tuberculosis in badgers. Proc Biol Sci 278(1713):1913-1920. https://doi.org/10. 1098/rspb.2010.1953

Cowan DP, Massei G (2008) Wildlife contraception, individuals and populations: how much fertility control is enough? In: Timm RM, Madon MB (eds) 23rd Vertebrate Pest Conference. University of California, Davis, pp 220-228

Cox DR (1972) Regression models and life-tables. J R Stat Soc Ser B (Methodol) 34(2):187-220 http://www.jstor.org/stable/2985181

Curtis PD, Pooler RL, Richmond ME, Miller LA, Mattfeld GF, Quimby FW (2002) Comparative effects of GnRH and porcine zona pellucida (PZP) immunocontraceptive vaccines for controlling reproduction in white-tailed deer (Odocoileus virginianus). Reprod Suppl 60: 131-141

Dalley D, Dave D, Lesellier S, Palmer S, Crawshaw T, Hewinson RG et al (2008) Development and evaluation of a gamma-interferon assay for tuberculosis in badgers (Meles meles). Tuberculosis (Edinb) 88(3):235-243. https://doi.org/10.1016/j.tube.2007.11.001

de Leeuw AN, Forrester GJ, Spyvee PD, Brash MG, Delahay RJ (2004) Experimental comparison of ketamine with a combination of ketamine, butorphanol and medetomidine for general anaesthesia of the Eurasian badger (Meles meles L.). Vet J 167(2):186-193. https://doi. org/10.1016/s1090-0233(03)00113-8

Defra (2018) Bovine TB: consultation on proposals to introduce licensed badger control to prevent the spread of bovine tuberculosis in the Low Risk Area (England). https://consult.defra.gov.uk/bovine-tb/ badger-control-in-low-risk-area-england/. Accessed 
Delahay RJ, Davison J, Poole DW, Matthews AJ, Wilson CJ, Heydon MJ et al (2009) Managing conflict between humans and wildlife: trends in licensed operations to resolve problems with badgers Meles meles in England. Mammal Rev 39(1):53-66. https://doi.org/10.1111/j. 1365-2907.2008.00135.x

Fagerstone KA, Miller LA, Killian G, Yoder CA (2010) Review of issues concerning the use of reproductive inhibitors, with particular emphasis on resolving human-wildlife conflicts in North America. Integr Zool 5(1):15-30. https://doi.org/10.1111/j.1749-4877.2010. 00185.x

Gavier-Widen D, Chambers MA, Palmer N, Newell DG, Hewinson RG (2001) Pathology of natural \&lt;em\&gt;Mycobacterium bovis\&lt; em\&gt; infection in European badgers (\&lt;em\&gt;Meles meles\&lt;/ em\&gt;) and its relationship with bacterial excretion. Vet Rec 148(10):299. https://doi.org/10.1136/vr.148.10.299 http:// veterinaryrecord.bmj.com/content/148/10/299.abstract

Gray ME, Thain DS, Cameron EZ, \& Miller LA (2010) Multi-year fertility reduction in free-roaming feral horses with single-injection immunocontraceptive formulations. USDA National Wildlife Research Center - Staff Publications. Available at: http:// digitalcommons.unl.edu/icwdm usdanwrc/1276

Hampton J, Hyndman T, Barnes A, Collins T (2015) Is wildlife fertility control always humane? Animals 5(4):0398 http://www.mdpi.com/ 2076-2615/5/4/0398

Harris S (1984) Ecology of urban badgers Meles meles: distribution in Britain and habitat selection, persecution, food and damage in the city of Bristol. Biol Conserv 28(4):349-375. https://doi.org/10. 1016/0006-3207(84)90041-7

Harris S, Baker PJ, Soulsbury CD (2010) Eurasian badgers (Meles meles). In: Gehrt SD, Riley SPD, Cypher BL (eds) Urban carnivores. John Hopkins University Press, Baltimore, MD, pp 109-119

Hearn JP (1974) The pituitary gland and implantation in the tammar wallaby, Macropus eugenii. J Reprod Fertil 39(1):235-241

Hinds LA, Evans SM, Tyndale-Biscoe CH (1983) In-vitro secretion of progesterone by the corpus luteum of the tammar wallaby, Macropus eugenii. J Reprod Fertil 67(1):57-63

Hone J (1992) Rate of increase and fertility control. J Appl Ecol 29(3): 695-698. https://doi.org/10.2307/2404478

Jenkins HE, Woodroffe R, Donnelly CA (2010) The duration of the effects of repeated widespread badger culling on cattle tuberculosis following the cessation of culling. PLoS One 5(2):e9090. https://doi. org/10.1371/journal.pone.0009090

Judge J, Wilson GJ, Macarthur R, Delahay RJ, McDonald RA (2014) Density and abundance of badger social groups in England and Wales in 2011-2013 (article). Sci Rep 4:3809. https://doi.org/10. 1038/srep03809

Kassambara A, Kosinski M (2018) Survminer: drawing survival curves using 'ggplot2'. R package version 0.4.2. https://CRAN.R-project. org/package $=$ survminer

Kirkpatrick JF (2007) Measuring the effects of wildlife contraception: the argument for comparing apples with oranges. Reprod Fertil Dev 19(4):548-552

Krause SK, Van Vuren DH, Laursen C, Kelt DA (2015) Behavioral effects of an immunocontraceptive vaccine on eastern fox squirrels. J Wildl Manag 79(8):1255-1263. https://doi.org/10.1002/jwmg.961

Lesellier S, Palmer S, Gowtage-Sequiera S, Ashford R, Dalley D, Dave D et al (2011) Protection of Eurasian badgers (Meles meles) from tuberculosis after intra-muscular vaccination with different doses of BCG. Vaccine 29(21):3782-3790. https://doi.org/10.1016/j. vaccine. 2011.03.028

Levy JK, Miller LA, Cynda Crawford P, Ritchey JW, Ross MK, Fagerstone KA (2004) GnRH immunocontraception of male cats. Theriogenology 62(6):1116-1130. https://doi.org/10.1016/j. theriogenology.2003.12.025

Levy JK, Friary JA, Miller LA, Tucker SJ, Fagerstone KA (2011) Longterm fertility control in female cats with GonaCon, a GnRH immunocontraceptive. Theriogenology 76(8):1517-1525. https:// doi.org/10.1016/j.theriogenology.2011.06.022

Massei G, Cowan D (2014) Fertility control to mitigate human-wildlife conflicts: a review. Wildl Res 41(1):1-21. https://doi.org/10.1071/ WR13141

Massei G, Cowan D, Coats J, Gladwell F, Lane JE, Miller LA (2008) Effect of the GnRH vaccine GonaConTM on the fertility, physiology and behaviour of wild boar

Massei G, Cowan DP, Coats J, Bellamy F, Quy R, Pietravalle S, Brash M, Miller LA (2012) Long-term effects of immunocontraception on wild boar fertility, physiology and behaviour. Wildl Res 39(5): 378-385. https://doi.org/10.1071/WR11196

Merrill JA, Cooch EG, Curtis PD (2003) Time to reduction: factors influencing management efficacy in sterilizing overabundant White-tailed deer. J Wildl Manag 67(2):267-279. https://doi.org/ $10.2307 / 3802768$

Miller LA, Johns BE, Killian GJ (2000) Immunocontraception of whitetailed deer with GnRH vaccine. Am J Reprod Immunol 44(5):266274

Miller LA, Rhyan J, Killian G (2004a) GonaCon ${ }^{\mathrm{TM}}$, a versatile GnRH contraceptive for a large variety of pest animal problems. ERM Timm and WP Gorenzel (eds) Proceedings of the Vertebrate Pest Conference. pp 269-273

Miller LA, Rhyan JC, Drew M (2004b) Contraception of bison by GnRH vaccine: a possible means of decreasing transmission of brucellosis in bison. J Wildl Dis 40(4):725-730. https://doi.org/10.7589/00903558-40.4.725

Miller LA, Gionfriddo JP, Fagerstone KA, Rhyan JC, Killian GJ (2008) The single-shot GnRH immunocontraceptive vaccine (GonaCon) in white-tailed deer: comparison of several GnRH preparations. Am J Reprod Immunol 60(3):214-223. https://doi.org/10.1111/j.16000897.2008.00616.x

Müller K (2017) Here: a simpler way to find your files. R package version 0.1. https://CRAN.R-project.org/package=here. $\mathrm{R}$ package version 0.1. Available at: https://CRAN.R-project.org/package=here

Murphy BD, Mead RA, McKibbin PE (1983) Luteal contribution to the termination of preimplantation delay in mink. Biol Reprod 28(2): 497-503

Neal EG (1977) Badgers. Blandford Press, Poole

Neal E, Cheeseman C (1996) Badgers. T \& A. D. Poyser Ltd., London

Neal EG, Harrison R (1958) Reproduction in the European badger (Meles meles). Trans Zool Soc Lond 29:67-131

Page RJC, Ross J, Langton SD (1994) Seasonality of reproduction in the European badger Meles meles in south-West England. J Zool 233(1):69-91. https://doi.org/10.1111/j.1469-7998.1994.tb05263.x

Quy RJ, Massei G, Lambert MS, Coats J, Miller LA, Cowan DP (2014) Effects of a GnRH vaccine on the movement and activity of freeliving wild boar (Sus scrofa). Wildl Res 41(3):185-193. https://doi. org/10.1071/WR14035

R Core Team (2017) R: A language and environment for statistical computing. R Foundation for Statistical Computing, Vienna, Austria. URL https://www.R-project.org/. 3.4.3. R Foundation for Statistical Computing, Vienna, Austria. Available at: https://www. R-project.org/

Ramsey D (2007) Effects of fertility control on behavior and disease transmission in Brushtail possums. J Wildl Manag 71(1):109-116. https://doi.org/10.2193/2005-699

Ramsey DS, Coleman JD, Coleman MC, Horton P (2006) The effect of fertility control on the transmission of bovine tuberculosis in wild brushtail possums. N Z Vet J 54(5):218-223. https://doi.org/10. 1080/00480169.2006.36700

Ransom JI, Powers JG, Garbe HM, Oehler MW, Nett TM, Baker DL (2014a) Behavior of feral horses in response to culling and GnRH immunocontraception. Appl Anim Behav Sci 157:81-92. https:// doi.org/10.1016/j.applanim.2014.05.002 
Ransom JI, Powers JG, Thompson Hobbs N, Baker DL (2014b) Review: ecological feedbacks can reduce population-level efficacy of wildlife fertility control. J Appl Ecol 51(1):259-269. https://doi.org/10. $1111 / 1365-2664.12166$

Smith GC (2002) The role of the badger (Meles meles) in rabies epizootiology and the implications for Great Britain. Mammal Rev 32(1): $13-26$

Smith GC, Cheeseman CL (2002) A mathematical model for the control of diseases in wildlife populations: culling, vaccination and fertility control. Ecol Model 150(1):45-53. https://doi.org/10.1016/S03043800(01)00471-9

Smith GC, Wilkinson D (2003) Modeling control of rabies outbreaks in red fox populations to evaluate culling, vaccination, and vaccination combined with fertility control. J Wildl Dis 39(2):278-286. https:// doi.org/10.7589/0090-3558-39.2.278

Therneau T (2015) A package for survival analysis in S. version 2.38, <URL: https://CRAN.R-project.org/package=survival>

Tuyttens FAM, Macdonald DW (1998) Sterilization as an alternative strategy to control wildlife diseases: bovine tuberculosis in European badgers as a case study. Biodivers Conserv 7(6):705723. https://doi.org/10.1023/A:1008830418123

White PCL, Lewis AJG, Harris S (1997) Fertility control as a means of controlling bovine tuberculosis in badger (Meles meles) populations in south-West England: predictions from a spatial stochastic simulation model. Proc R Soc Lond Ser B Biol Sci 264(1389):17371747. https://doi.org/10.1098/rspb.1997.0241

Wickham H (2009) ggplot2: elegant graphics for data analysis. SpringerVerlag, New York

Wickham H (2017) Scales: scale functions for visualization. R package version 0.5.0. https://CRAN.R-project.org/package=scales
Wickham H, Henry L (2017) Tidyr: easily tidy data with 'spread()' and 'gather()' functions. R package version 0.7.2. https://CRAN.Rproject.org/package=tidyr

Wickham H, Francois R, Henry L, Müller K (2017) Dplyr: a grammar of data manipulation. $\mathrm{R}$ package version 0.7.4. https:/CRAN.Rproject.org/package $=$ dplyr

Woodroffe R, Macdonald DW (1995) Costs of breeding status in the European badger, Meles meles. J Zool 235(2):237-245. https://doi. org/10.1111/j.1469-7998.1995.tb05140.x

Woodroffe R, Donnelly CA, Cox DR, Gilks P, Jenkins HE, Johnston WT, le Fevre AM, Bourne FJ, Cheeseman CL, Clifton-Hadley RS, Gettinby G, Hewinson RG, McInerney JP, Mitchell AP, Morrison WI, Watkins GH (2009) Bovine tuberculosis in cattle and badgers in localized culling areas. J Wildl Dis 45(1):128-143. https://doi.org/ 10.7589/0090-3558-45.1.128

Yamaguchi N, Dugdale HL, Macdonald DW (2006) Female receptivity, embryonic diapause, and superfetation in the European badger (Meles meles): implications for the reproductive tactics of males and females. Q Rev Biol 81(1):33-48

Zeileis A, Grothendieck G (2005) Zoo: S3 infrastructure for regular and irregular time series. J Stat Softw 14(6):1-27. https://doi.org/10. 18637/jss.v014.i06

Publisher's note Springer Nature remains neutral with regard to jurisdictional claims in published maps and institutional affiliations. 